\title{
An enzyme activity capable of endotransglycosylation of heteroxylan polysaccharides is present in plant primary cell walls
}

Sarah L. Johnston · Roneel Prakash · Nancy J. Chen · Monto H. Kumagai · Helen M. Turano · Janine M. Cooney · Ross G. Atkinson · Robert E. Paull · Roshan Cheetamun · Antony Bacic · David A. Brummell · Roswitha Schröder

S. L. Johnston • R. Prakash • R. G. Atkinson· R. Schröder $(\bowtie)$ The New Zealand Institute for Plant \& Food Research Limited, Mount Albert Research Centre, Private Bag 92169, Auckland 1142, New Zealand e-mail: rosie.schroeder@plantandfood.co.nz

N. J. Chen • M. H. Kumagai • H. M. Turano $\cdot$ R. E. Paull Department of Tropical Plant and Soil Sciences, University of Hawaii at Manoa, 3190 Maile Way, Honolulu, Hawaii HI 96822-2279, USA

\section{J. M. Cooney}

The New Zealand Institute for Plant \& Food Research Limited, Ruakura Research Centre, Private Bag 3123, Hamilton 3240, New Zealand

A. Bacic $\cdot$ R. Cheetamun ARC Centre of Excellence in Plant Cell Walls, School of Botany, University of Melbourne, VIC 3010, Australia

D. A. Brummell

The New Zealand Institute for Plant \& Food Research Limited, Food Industry Science Centre, Private Bag 11600, Palmerston North 4442, New Zealand

Present address:

M. H. Kumagai

XtremeSignPost Inc., Leucadia, CA 92024, USA 


\begin{abstract}
Heteroxylans in the plant cell wall have been proposed to have a role analogous to that of xyloglucans or heteromannans, forming growth-restraining networks by interlocking cellulose microfibrils. A xylan endotransglycosylase has been identified that can transglycosylate heteroxylan polysaccharides in the presence of xylan-derived oligosaccharides. High activity was detected in ripe fruit of papaya (Carica papaya), but activity was also found in a range of other fruits, imbibed seeds and rapidly-growing seedlings of cereals. Xylan endotransglycosylase from ripe papaya fruit used a range of heteroxylans, such as wheat arabinoxylan, birchwood glucuronoxylan and various heteroxylans from dicotyledonous primary cell walls purified from tomato and papaya fruit, as donor molecules. As acceptor molecules, the enzyme preferentially used xylopentaitol over xylohexaitol or shorter-length acceptors. Xylan endotransglycosylase was active over a broad pH range, and could perform transglycosylation reactions up to $55^{\circ} \mathrm{C}$. Xylan endotransglycosylase activity was purified from ripe papaya fruit by ultrafiltration and cation exchange chromatography. Highest endotransglycosylase activity was identified in fractions that also contained high xylan hydrolase (xylanase) activity, and correlated with the presence of the endoxylanase CpaEXY1. Recombinant CpaEXY1 protein transiently over-expressed in Nicotiana benthamiana leaves showed both endoxylanase and xylan endotransglycosylase activities in vitro, suggesting that CpaEXY1 is a single enzyme with dual activity in planta. Purified native CpaEXY1 showed 2 to 4fold higher endoxylanase activity than endotransglycosylase activity, suggesting that CpaEXY1 may act primarily as a hydrolase. We propose that xylan endotransglycosylase activity (like xyloglucan and mannan endotransglycosylase activities) could be involved in remodelling or rearrangement of heteroxylans of the cellulose-non-cellulosic cell wall framework.
\end{abstract}

Keywords: Cell wall, Endoxylanase, Heteroxylan, Papaya, Xylan endotransglycosylase

\title{
Abbreviations
}

CTAB Cetyltrimethylammonium bromide

WAX Wheat arabinoxylan

PAHBAH $\quad p$-hydroxybenzoic acid hydrazide

XET Xyloglucan endotransglycosylase

XTH Xyloglucan endotransglycosylase/ hydrolase

$\mathrm{Xyl}_{2}$-ol Xylobiitol 


$\begin{array}{ll}\mathrm{Xyl}_{3}-\mathrm{ol} & \text { Xylotriitol } \\ \mathrm{Xyl}_{4} \text {-ol } & \text { Xylotetraitol } \\ \mathrm{Xyl}_{5}-\mathrm{ol} & \text { Xylopentaitol } \\ \mathrm{Xyl}_{6} \text {-ol } & \text { Xylohexaitol }\end{array}$

\section{Introduction}

The framework upon which the primary cell wall of land plants is based, and from which it derives its strength, is a structural network of cellulose microfibrils held together noncovalently by pectins and a group of polysaccharides known as the hemicelluloses (Park and Cosgrove 2012). The resulting network forms the major load-bearing structure in the primary cell wall and, apart from providing support, is also responsible for restricting growth. Plants have mechanisms for loosening and modifying this structure during growth and development without loss of wall strength, allowing turgor-driven cell expansion and the incorporation of new materials into the expanding wall.

The composition of hemicelluloses varies with species, tissue types and stages of development, but is diverse and usually consists of xyloglucans, heteroxylans (xylans) and heteromannans in varying proportions. In the primary walls of dicotyledonous plants and noncommelinoid monocotyledons, the most abundant hemicellulose is xyloglucan, a polysaccharide with a $(1 \rightarrow 4)-\beta$-D-glucan backbone that is regularly substituted with xylose residues and, depending on species and tissue, can be further decorated with galactose, fucose and/or arabinose as well as non-glycosyl (o-acetyl) residues. The integration of new xyloglucan into the wall is accomplished by the endotransglycosylase activity of xyloglucan endotransglycosylase/hydrolases (XTH). Here, a xyloglucan chain is cleaved by xyloglucan endotransglycosylase (XET) activity and the newly-created reducing end attached to the nonreducing end of another xyloglucan molecule (Farkaš et al. 1992; Fry et al. 1992; Nishitani and Tominaga 1992). XTHs are members of a large gene family with most members possessing only XET activity and lacking xyloglucanase activity, although a few proteins are predominantly xyloglucanases and have the potential for XET activity under certain conditions (Eklöf and Brumer 2010; Baumann et al. 2007). Xyloglucanase activity is most commonly present in germinating seeds, where the activity hydrolyses storage xyloglucans to provide substrates for the growing embryo (Edwards et al. 1986), and in ripening fruit during fruit softening (Maclachlan and Brady 1994).

Heteromannans have a backbone consisting either of $(1 \rightarrow 4)-\beta$-D-mannan (mannans, galactomannans) or of alternating regions of $(1 \rightarrow 4)$ - $\beta$-D-mannose and $(1 \rightarrow 4)-\beta$-D-glucose 
which can be either unsubstituted (glucomannan) or substituted with galactose (galactoglucomannan) (Melton et al. 2009). Glucomannans and galactoglucomannans also contribute to non-covalent microfibril cross-linking, although galactoglucomannans are generally shorter polymers than xyloglucans and bind less strongly to cellulose (Whitney et al. 1998). A mannan endotransglycosylase activity has been characterised in ripe tomato fruit and was identified as the endo- $\beta$-mannanase LeMAN4 (Schröder et al. 2004, 2006). Unlike most XTH proteins, LeMAN4 is a dual activity enzyme. Whereas endo- $\beta$-mannanase activity is associated with the breakdown of mannans either during seed germination or fruit softening (Bewley et al. 1997, 2000), mannan endotransglycosylase activity has been proposed to have an equivalent role to XET in the plant cell wall, remodelling it during all developmental stages (Schröder et al. 2009).

Heteroxylans are a divergent group of polymers consisting of a $(1 \rightarrow 4)-\beta$-D-xylan backbone, which is substituted in all land plants with short side chains (usually monosaccharide) of arabinose and/or glucuronic acid residues. In the primary walls of the commelinoid monocots, that includes the Poales (grasses), glucuronoarabinoxylans constitute up to $40 \%$ of the wall, where, together with unbranched $(1 \rightarrow 3,1 \rightarrow 4)$ - $\beta$-D-glucan, they are the major structural non-cellulosic polysaccharide (Brummell and Schröder 2009). Heteroxylans are also commonly present as structural components in the primary cell walls of dicots, although they are less abundant than xyloglucan. The structure and properties of these dicot xylans are less well known, as are the potential modifications occurring during the cell wall loosening that allow growth and during the cell wall disassembly that cause fruit softening. It is likely that in both dicot and commelinoid monocots cell walls, heteroxylans interact noncovalently with cellulose and form inter-microfibril cross links, in a manner similar to that of either xyloglucans or mannans, although the interactions are less strong (Carpita 1983).

Endo-(1 $\rightarrow 4)$ - $\beta$-xylanase (endoxylanase) activity is well known in plants, including in germinating seeds of some monocots (notably cereals) and dicots, and in ripening fruit tissue of some dicot species (Brummell and Schröder 2009). Plant endoxylanases are typically found as small gene families, for example 12 genes in Arabidopsis and 10 in rice (Yokoyama and Nishitani 2004), and at least 4 and possibly 6 genes in papaya (Ming et al. 2008). Arabidopsis possesses four putative endo-1,4- -xylanases with a putative signal sequence for secretion to the apoplast, suggesting that heteroxylan metabolism is involved in some aspects of plant development. A large increase in endoxylanase activity accompanies fruit ripening in papaya (Paull and Chen 1983), indicating that in some species heteroxylan depolymerisation may be a component of the wall disassembly leading to fruit softening. All plant endoxylanases undergo extensive post-translational modifications where $\mathrm{C}$ - and $\mathrm{N}$-terminal ends, possibly acting as 
chaperones during protein folding, are removed before a catalytic domain of approximately 32 $\mathrm{kDa}$ is released, representing the active enzyme (Brummell and Schröder 2009).

We have previously proposed that a xylan endotransglycosylase activity analogous to XET and mannan endotransglycosylase is likely to exist in higher plants (Schröder et al. 2009, 2010). Endotransglycosylase reactions involving xylo-oligosaccharides have been reported for bacterial xylanases, where xylo-oligosaccharides acted both as donor and acceptor, and acceptor concentrations had to be in the $\mathrm{mM}$ range for the transglycosylation reaction to occur (Roberge et al. 1999; Moreau et al. 1994). A similar reaction has been described for fungal glucanases (Biely et al. 1991), as well as for plant endo- $\beta$-mannanases (e.g. Coulombel et al. 1981; Marraccini et al. 2001) and xylan endo- and exotransglycosylases from several plant species, including oat and broad bean (Franková and Fry 2011; here named trans- $\beta$-xylanases and trans- $\beta$-xylosidases, respectively).

In this paper, we report the presence of xylan endotransglycosylase activities in a wide range of tissues and species, including ripe fruit, imbibed seeds and rapidly growing seedlings, by using high molecular weight polymeric heteroxylan polysaccharide donor substrates and tritiated xylo-oligosaccharides as acceptor substrates, with acceptor substrate concentrations being in the $\mu \mathrm{M}$ range. In papaya, we show that xylan endotransglycosylase activity increases as the fruit ripens, characterise its biochemical properties, and show that it co-purifies with the xylanase CpaEXY1. The potential roles of xylan endotransglycosylase activity during rearrangement of cell walls are discussed.

\section{Materials and methods}

Plant material

Papaya fruit Carica papaya L., 'Rainbow' and 'Sunset' fruit were harvested from the University of Hawaii at Manoa's Poamoho Experiment station in Central Oahu, Hawaii, USA and ripened at $22^{\circ}$ C.Papaya fruit 'Sunrise' from Fiji and a yellow-fleshed variety of 'Solo' parentage termed 'PPY' from the Philippines were purchased at a local fruit market in Auckland, New Zealand. Ripeness was determined by skin colour (green = unripe, 50\% yellow $=$ medium ripe, $100 \%$ yellow = ripe). Ripe pineapple (Ananas comosus), banana (Musa domestica), avocado (Persea americana), kiwifruit (Actinidia deliciosa 'Hayward'), apple (Malus pumila 'Royal Gala'), pear (Pyrus communis 'Packham's Triumph'), Ya pear (Pyrus bretschneideri), and cucumber (Cucumis sativus) and celery (Apium graveolens var. dulce) were purchased at a local fruit market in Auckland, New Zealand. Fungicide-free barley, maize, oat and wheat seeds were purchased from 
Newton Seeds (Onehunga, Auckland, New Zealand). The seeds were sterilized for 30 min in 1\% bleach with a few drops of Tween 20, rinsed with sterile water, placed onto moist cotton wool in sterile clear plastic dishes, and kept at $21^{\circ} \mathrm{C}$ under a $12 \mathrm{~h}$ light followed by $12 \mathrm{~h}$ dark cycle. Imbibed seeds were harvested when the radicle had just emerged (max. $1 \mathrm{~mm}$ long). Seedlings were harvested (without root) at 2 to $3 \mathrm{~cm}$ long. All tissues were snap-frozen in liquid $\mathrm{N}_{2}$ and stored at $-80^{\circ} \mathrm{C}$.

Crude enzyme extractions

Tissue was finely ground in liquid $\mathrm{N}_{2}$ and extracted with 5 volumes of $0.1 \mathrm{M} \mathrm{Mes,} \mathrm{pH} \mathrm{5.5,}$ containing 1.3 M NaCl, 0.2 M EDTA and protease inhibitor (Complete ${ }^{\mathrm{TM}}$, Roche). After thawing on ice, the extract was mixed by vortexing, left on ice for $45 \mathrm{~min}$, and centrifuged at $11,000 \mathrm{~g}$ for 10 $\min$ at $4^{\circ} \mathrm{C}$. The supernatant was collected and assayed for xylan endotransglycosylase and endoxylanase activity.

Polysaccharide and oligosaccharide substrates for endotransglycosylase assays

Wheat arabinoxylan (WAX; low viscosity) and birchwood xylan were purchased from Megazyme (Bray, Ireland). Xyloglucan and galactoglucomannan from kiwifruit were purified as described in Schröder et al. (2001). Polygalacturonic acid from citrus was purchased from Sigma, St Louis, MO).

Heteroxylans ( $1 \mathrm{M}$ and $4 \mathrm{M} \mathrm{KOH}$-soluble) from tomato and papaya were prepared from cell walls of ripe papaya fruit 'PPY' and tomato (Solanum lycopersicum 'Daniela') by homogenising in methanol-chloroform-water-formic acid (16:5:1:1, by vol.), and then sequentially extracted using dimethylsulfoxide, trans-1,2-cyclohexane diaminetetraacetic acid, $\mathrm{Na}_{2} \mathrm{CO}_{3}, 1 \mathrm{M} \mathrm{KOH}$ and $4 \mathrm{M} \mathrm{KOH}$ as described in Prakash et al. (2012). Heteroxylans were purified from $1 \mathrm{M} \mathrm{KOH}$ - and $4 \mathrm{M} \mathrm{KOH}$-soluble fractions by precipitation with cetyltrimethylammonium bromide (CTAB) as described in Schröder et al. (2001). In brief, fractions (1 M and $4 \mathrm{M} \mathrm{KOH-}$ soluble) were dissolved in water, CTAB (1\%, by vol.) added to a final concentration of $0.05 \%$ (by vol.), and heteroxylans precipitated overnight at room temperature. The pellet was recovered by centrifugation and suspended in $4 \mathrm{M} \mathrm{NaCl}$. CTAB was removed by repeatedly adding ethanol saturated with Na-acetate crystals, and the precipitate allowed to sediment. The precipitate was dissolved in water and dialysed against water and freeze-dried. Sugar composition was analysed according to Albersheim et al. (1967), Blumenkrantz and Asboe-Hansen (1973) and Ahmed and Labavitch (1977). 
Galactoglucomannan-glucuronoxylan I and II (GGM-GX I, II) were prepared from ripe tomato cell walls according to Prakash et al. (2012). GGM-GX I was purified from the DMSO extract and GGM-GX II from the CTAB supernatant of the $4 \mathrm{M} \mathrm{KOH}$ extract. Linkage analysis by methylation of GGM-GX I was carried out as described by Pettolino et al. (2012).

For analysis of rate of hydrolysis, reduced WAX was used to keep background reducing power low in reducing end assays. WAX $(250 \mathrm{mg})$ was incubated with $\mathrm{NaB}\left(\mathrm{H}_{4}\right)\left(10 \mathrm{mg} \mathrm{mL}^{-1}\right.$, total volume $25 \mathrm{~mL}$ ) overnight at room temperature. The reaction was stopped using glacial acetic acid until $\mathrm{H}_{2}$ production ceased. Salts were removed by dialysis for $5 \mathrm{~d}$ at $4^{\circ} \mathrm{C}$ against water (molecular weight cut-off $12 \mathrm{kDa}$; daily water change), and the dialysate freeze-dried to give reduced WAX.

Heteroxylan-derived oligosaccharides (xylo-oligosaccharides) were purchased from Megazyme. For general xylan endotransglycosylase assays, xylotriose $\left(\mathrm{Xyl}_{3}\right)$, xylotetraose $\left(\mathrm{Xyl}_{4}\right)$ and xylopentaose $\left(\mathrm{Xyl}_{5}\right)$ were mixed at a ratio of 1:1.4:2.4 (by weight), and tritiated in $0.2 \mathrm{M}$ $\mathrm{NaOH}$ as described in Schröder et al. (2006) using 0.74 GBq NaB $\left[{ }^{3} \mathrm{H}\right]_{4}$ (American Radiolabeled Chemicals, St Louis, MO) by conversion to alditols. The tritiated xylo-oligosaccharide alditols were desalted, freeze-dried and dissolved in water $\left(4 \mu \mathrm{g} \mu \mathrm{L}^{-1}\right.$; specific activity $37.3 \mathrm{kBq} \mu \mathrm{g}^{-1}$ or, on average, approximately $22 \mathrm{MBq}^{\mathrm{m}} \mathrm{mol}^{-1}$ ).

For determination of oligosaccharide specificity of crude papaya xylan endotransglycosylase, $3.1 \mathrm{mg} \mathrm{Xyl}$ (xylobiose), and 7.0 - $7.5 \mathrm{mg} \mathrm{Xyl}_{3}, \mathrm{Xyl}_{4}, \mathrm{Xyl}_{5}$ and $\mathrm{Xyl}_{6}$ (xylohexaose) were tritiated individually, using $0.481 \mathrm{GBq} \mathrm{NaB}\left[{ }^{3} \mathrm{H}\right]_{4}$ for $\mathrm{Xyl}_{3}, \mathrm{Xyl}_{4}$ and $\mathrm{Xyl}_{5}$ and $0.37 \mathrm{GBq} \mathrm{NaB}\left[{ }^{3} \mathrm{H}\right]_{4}$ for $\mathrm{Xyl}_{2}$ and $\mathrm{Xyl}_{6}$. The specific activity of the corresponding tritiated alditols was 96.4, 49.2, 42.5, 21.7 and $35 \mathrm{kBq} \mu^{-1}$, respectively (or, on a molar base, 27.7, 20.4, 23.2,

\section{7, 28.4 MBq mol-1 $^{-1}$ resepctively).}

For enzyme kinetics, $\mathrm{Xyl}_{5}(10 \mathrm{mg})$ was tritiated with $0.74 \mathrm{GBq} \mathrm{NaB}\left[{ }^{3} \mathrm{H}\right]_{4}$, giving a specific activity of $50.3 \mathrm{kBq} \mathrm{\mu g}^{-1}$ (34 MBq $\mu \mathrm{mol}^{-1}$ ). Tritiated oligosaccharides were counted using Liquid Scintillation Cocktail (ACS-II, Amersham), with a counting efficiency of $28 \%$.

Xylan endotransglycosylase assays

Reaction mixtures $(20 \mu \mathrm{L})$ contained $0.25 \%(\mathrm{w} / \mathrm{v})$ polysaccharide solution and $0.04 \%(\mathrm{w} / \mathrm{v})$ $\left[{ }^{3} \mathrm{H}\right] \mathrm{Xyl}_{3}-\mathrm{ol},\left[{ }^{3} \mathrm{H}\right] \mathrm{Xyl}_{4}$-ol and $\left[{ }^{3} \mathrm{H}\right] \mathrm{Xyl}_{5}$-ol mixture $(298 \mathrm{kBq})$ in $0.2 \mathrm{M}$ Mes-NaOH buffer, $\mathrm{pH} 5.5$. Reactions were carried out at $21^{\circ} \mathrm{C}$. Volumes of extract and incubation time were adjusted as needed to provide linearity of assays. Reactions were stopped by adding $50 \mu \mathrm{L}$ of $40 \%(\mathrm{v} / \mathrm{v})$ formic acid. Background reactions were performed by adding formic acid before the enzyme extract, and values subtracted from those obtained using active enzyme extract. The $\left[{ }^{3} \mathrm{H}\right]-$ labelled polysaccharides produced in the assays were separated from un-reacted 
$\left[{ }^{3} \mathrm{H}\right]$ oligosaccharides by their immobility during paper chromatography. Reaction products were applied to $46 \times 27 \mathrm{~cm}$ sheets of 3MM paper (Whatman, Maidstone, UK) and mobile, unreacted $\left[{ }^{3} \mathrm{H}\right]$ oligosaccharides were removed by chromatography in ethyl acetate:acetic acid:water (10:5:6, by vol.) for $48 \mathrm{~h}$ after Fry et al. (1992). Initial trials using [ $\left.{ }^{3} \mathrm{H}\right]$ xylooligosaccharides and WAX without addition of active enzyme showed background radioactivity of approximately $5 \%$ with a standard deviation of $0.23 \%$ remaining at the site of original application. The addition of enzyme in background reactions mentioned above, or other donor substrates than WAX, did not significantly influence this value (data not shown). After chromatography, the paper was dried; the spots where the reaction mixture had been applied were cut out, and assayed for ${ }^{3} \mathrm{H}$ by liquid scintillation counting using organic counting scintillant (OCS, Amersham) with a counting efficiency of 40\%. Endotransglycosylase activities are given as $\mathrm{Bq}$ of radioactivity incorporated into high molecular weight products per $\mathrm{kBq}$ of radioactive oligosaccharides supplied per $\mathrm{h}$, or as indicated.

\section{Endoxylanase assays}

Endoxylanase activity was determined by measuring the release of Remazol dye from watersoluble birch xylan after Chen and Paull (2003). The substrate [0.4 mL of 0.1\% 4-O-methyl-Dglucurono-D-xylan-Remazol Brilliant Blue (RBB) (Sigma) and $10 \mu \mathrm{g}$ bovine serum albumin in 50 $\mathrm{mM}$ citric acid, pH 5.5] was incubated with enzyme extract and buffer (final volume $50 \mu \mathrm{L}$ ) at $37^{\circ} \mathrm{C}$. Incubation time was $4 \mathrm{~h}$ unless indicated otherwise. The reaction was terminated by the addition of $95 \%$ ethanol $(0.9 \mathrm{~mL})$ to precipitate non-degraded xylan-RBB. After $20 \mathrm{~min}$, the mixture was centrifuged at $16000 \mathrm{~g}$ for $10 \mathrm{~min}$ and the absorbance of the supernatant measured at $595 \mathrm{~nm}$.

Purification of xylan endotransglycosylase activity from papaya fruit

Ripe mesocarp of 'Rainbow' (100\% yellow skin colour, flesh firmness of ca. $27 \mathrm{~N}$ ) was blended in $25 \mathrm{~mL}$ of ice-cold buffer ( $50 \mathrm{mM} \mathrm{NaH}_{2} \mathrm{PO}_{4}$, $\mathrm{pH} 4.5,1 \mathrm{mM}$ dithiopyridine, $1 \mathrm{mM}$ phenylmethylsulfonyl fluoride) until smooth, then centrifuged at $2^{\circ} \mathrm{C}$ at $14000 \mathrm{~g}$ for $15 \mathrm{~min}$ (Chen and Paull 2003). The supernatant was filtered through Miracloth (Calbiochem, San Diego, $\mathrm{CA}$ ), and soluble pectin removed by ultrafiltration (MWCO $100 \mathrm{kDa}$ ). The flow-through containing xylan endotransglycosylase activity was concentrated by ultrafiltration (MWCO 10 $\mathrm{kDa})$, and the retentate $(1 \mathrm{~mL})$ loaded onto S-Sepharose $(10 \times 10 \mathrm{~mm}$; GE Healthcare, Piscataway, NJ) equilibrated in $50 \mathrm{mM}$ phosphate buffer, $\mathrm{pH} 4.5$, and eluted at a flow rate $1 \mathrm{~mL}$ min $^{-1}$ with $10 \mathrm{~mL} 200 \mathrm{mM} \mathrm{NaCl}$ in phosphate buffer, $\mathrm{pH}$ 4.5. After de-salting and concentrating 
the eluate by ultrafiltration (MWCO $10 \mathrm{kDa}$ ), the retentate $(1 \mathrm{~mL})$ was applied to a column of MonoS HR 5/5 (GE Healthcare) equilibrated in phosphate buffer, $\mathrm{pH} 4.5$, and eluted using a salt gradient from 0 to $500 \mathrm{mM} \mathrm{NaCl}$, collecting $1 \mathrm{~mL}$ fractions. Fractions were assayed for xylan endotransglycosylase and xylanase activity.

For determining enzyme kinetics, activity was purified from ripe papaya 'PPY' fruit with the following modifications. After ultrafiltration ( $100 \mathrm{kDa}$ followed by $30 \mathrm{kDa})$, the $30 \mathrm{kDa}$ retentate (approximately $5 \mathrm{~mL}$, equilibrated in $50 \mathrm{mM} \mathrm{NaOAc}$, pH 5.0) was loaded onto a HiTrap SP HP column ( $5 \mathrm{~mL}$ bed volume) equilibrated in $50 \mathrm{mM} \mathrm{NaOAc}$, pH 5.0, and eluted with a linear gradient of $50 \mathrm{mM} \mathrm{NaOAc} / 0 \mathrm{mM} \mathrm{NaCl}$ to $50 \mathrm{mM} \mathrm{NaOAc} / 500 \mathrm{mM} \mathrm{NaCl}$ over $50 \mathrm{~mL}$, then to 50 $\mathrm{mM} \mathrm{NaOAc} / 1000 \mathrm{mM} \mathrm{NaCl}$ over $10 \mathrm{~mL}$, and $2 \mathrm{~mL}$ fractions were collected. Fractions were assayed for xylan endotransglycosylase and xylanase activity. Fractions 12 and 13 were similar with respect to enzyme activities and purity as fraction 16 of the previous purification (data not shown).

Transient expression of recombinant CpaEXY1 protein in Nicotiana benthamiana Domin

The complete open reading frame of endoxylanase CpaEXY1 (GenBank accession number AY138986, Chen and Paull 2003) was PCR-amplified using forward primer 5'-ACAGCATGCA GCTTGGAGAG AAGAACTTAC AG-3' and reverse primer 5'-AATCCTAGGT TAAACTTTAA TGAGAAGTAA TCTTGTTTG-3'. These primers added a unique SphI site at the translation initiation ATG (and changed the second amino acid residue from Lys to Gln), and added an AvrII site immediately downstream of the translation stop. The $1.7 \mathrm{~kb}$ PCR product was ligated into the viral vector TTOSA1 APE (Kumagai et al. 2000) that had been digested with SphI and AvrII, placing the CPaEXY1 transgene under the control of a tobamovirus subgenomic promoter, to produce plasmid TTOSA1-XYL. Approximately 10 days after inoculation of lower leaves of young plants of $N$. benthamiana, leaf tissue from plants transfected with TTOSA1-XYL or with empty TTOSA1 vector, respectively, was finely ground in liquid $\mathrm{N}_{2}$ and extracted with $50 \mathrm{mM}$ sodium citrate, $\mathrm{pH} 4.5$, containing $1 \mathrm{mM}$ dithiopyridine, $1 \mathrm{mM}$ phenylmethylsulfonyl fluoride. The supernatant was recovered after centrifugation and assayed for xylan endotransglycosylase and endoxylanase activity. Protein contents of extracts were $0.539 \mu \mathrm{g} \mu \mathrm{L}^{-1}$ (TTOSA1-XYL) and $1.108 \mu \mathrm{g} \mu \mathrm{L}^{-1}$ (empty TT0SA1 vector).

Polyacrylamide gel electrophoreses and protein gel blot analyses

Proteins were separated by one-dimensional SDS-PAGE using 10\% polyacrylamide separating gels, which were stained with colloidal Coomassie stain. Protein molecular mass markers used 
were Precision Plus Protein ${ }^{\mathrm{TM}}$ Dual Color (Bio-Rad, Hercules, CA). Protein concentrations were determined using a Protein Assay Kit (Bio-Rad) with bovine serum albumin as a standard. Protein gels were electroblotted to polyvinylidene fluoride membrane and immunodetection carried out as described in Nieuwenhuizen et al. (2007) using antibodies developed against the xylanase catalytic module from papaya (Manenoi and Paull 2007) at a concentration of 1:5000 (by vol.) and gel blots developed using goat anti-rabbit IgG-alkaline phosphatase secondary antibody (Sigma) and 1-Step NBT/BCIP as substrate (Pierce Chemicals, Dallas, TX). Protein gel images were scanned using a Typhoon 9400 Variable Mode Imager (GE Healthcare).

Peptide sequencing

Proteolytic fragments of the protein gel band corresponding to the major xylanase band after protein gel blot analysis, and using an aliquot of fraction 16 eluted from the MonoS column, were generated by digestion with trypsin. Gel fragments and $100 \mu \mathrm{g}$ of protein from fraction 16 from the MonoS column were reduced with $10 \mathrm{mM}$ DTT then alkylated with $10 \mathrm{mM}$ iodoacetamide to prepare for tryptic digestion, which was performed following Jimenez et al. (2003). The peptide fragments were analyzed by LC-MS at Plant \& Food Research, Ruakura, New Zealand against a database of all proteins in the papaya genome (http://www.phytozome.net/papaya.php).

Enzyme kinetics of xylan endotransglycosylase and endoxylanase activities of native CpaEXY1 protein

Assays for hydrolysis contained the following: WAX (reduced; $0.2 \%$ or $0.4 \%$ final concentration w/v), NaOAc pH 5.5 (32 mM), and purified native CpaEXY1 enzyme from ripe papaya 'PPY' $\left(0.007 \mu \mathrm{g} \mu \mathrm{L}^{-1}\right.$ protein) in a total volume of $250 \mu \mathrm{L}$. Reactions were stopped by adding $750 \mu \mathrm{L}$ PAHBAH reagent (1\% p-hydroxybenzoic acid hydrazide in $0.5 \mathrm{M} \mathrm{NaOH}$ ). To determine the number of reducing ends created through hydrolysis, samples were boiled for $5 \mathrm{~min}$, and after cooling, absorbance was measured at $410 \mathrm{~nm}$ (Lever, 1972). For $\mathrm{t}=0$, PAHBAH reagent was added before addition of enzyme. Total $A_{410}$ values obtained with inactive enzyme ( $\mathrm{t}=0$ ) were subtracted from total $A_{410}$ values obtained with active enzyme, and for determination of the hydrolysis reaction rate the nmol of reducing ends generated per minute per $\mu$ g protein were calculated. Xylose in $50 \mathrm{mM} \mathrm{NaOAc}$ (pH 5.5) was used to create a standard curve.

Assays for transglycosylation were the same as the assays for hydrolysis except for the presence of [ $\left.{ }^{3} \mathrm{H}\right] \mathrm{Xyl}_{5}-\mathrm{ol}$, in a total volume of $25 \mu \mathrm{L}$. [ $\left.{ }^{3} \mathrm{H}\right] \mathrm{Xyl}_{5}-\mathrm{ol}$ acceptors were tested at 467, 234, and $117 \mu \mathrm{M}$ over a time period of $60 \mathrm{~min}$. At $234 \mu \mathrm{M}$ acceptor concentration and $30 \mathrm{~min}$ 
reaction time, three different donor concentrations were tested. The reactions were terminated by adding $50 \mu \mathrm{L}$ of formic acid (40\%), un-reacted $\left[{ }^{3} \mathrm{H}\right] \mathrm{Xyl}_{5}$-ol acceptors were removed by paper chromatography, and enzyme activity quantified by scintillation counting using non-aqueous scintillant (counting efficiency $40 \%$ ) as described above. The radioactivity per nmol acceptor $\left[{ }^{3} \mathrm{H}\right] \mathrm{Xyl}_{5}-\mathrm{ol}$ offered in the reactions was estimated by counting appropriate concentrations on paper using non-aqueous scintillant, as the cpm values of tritiated oligosaccharides on paper were lower than in solution, presumably because they penetrate into the paper matrix (Fry et al. 1992). Results were calculated as nmol $\left[{ }^{3} \mathrm{H}\right] \mathrm{Xyl}_{5}-\mathrm{ol}$ incorporated per minute per $\mu \mathrm{g}$ protein, assuming each molecule of acceptor incorporated into WAX equalled an endotransglycosylase reaction. All reactions were carried out at $21^{\circ} \mathrm{C}$.

\section{Results}

Characterisation of xylan endotransglycosylase activity in papaya extracts

Xylan endotransglycosylase activity was detected in crude extracts of ripe papaya fruit mesocarp by measuring the incorporation of tritiated $\left(\left[{ }^{3} \mathrm{H}\right]\right)$ xylo-oligosaccharide substrates into a high molecular weight polymeric wheat arabinoxylan (WAX) substrate. The assay required removal of un-reacted $\left[{ }^{3} \mathrm{H}\right]$-xylo-oligosaccharides by their differential mobility during paper chromatography. This procedure was used, rather than the 'paper-binding assay' for assay of XET and mannan endotransglycosylase (Fry et al. 1992; Schröder et al. 2004), since neither WAX nor the tomato heteroxylans tested bound well to paper under aqueous conditions (data not shown). As acceptors, a mixture of [ $\left.{ }^{3} \mathrm{H}\right]$-xylo-oligosaccharides $\left(\left[{ }^{3} \mathrm{H}\right]-\mathrm{Xyl}_{3}-\mathrm{Ol},\left[{ }^{3} \mathrm{H}\right]-\mathrm{Xyl}_{4}\right.$ ol and $\left[{ }^{3} \mathrm{H}\right]-\mathrm{Xyl}_{5}-\mathrm{ol}$ ) was chosen to maximize the chance of discovering the activity. Using crude papaya extract $(10 \mu \mathrm{L})$ and a donor substrate concentration of $0.25 \%(\mathrm{w} / \mathrm{v})$ with $0.04 \%(\mathrm{w} / \mathrm{v})$ $\left[{ }^{3} \mathrm{H}\right]$ xylo-oligosaccharides as acceptor, the assay was approximately linear for up to $180 \mathrm{~min}$ (data not shown). Therefore, xylan endotransglycosylase assays were routinely carried out under these substrate conditions and at a shortened assay time of $60 \mathrm{~min}$.

To prove that the radioactive oligosaccharides were incorporated into high molecular weight WAX, the xylan endotransglycosylase product was treated with either trypsin or with a mixture of fungal xylanases (Prakash et al. 2012), respectively, and paper chromatography carried out to test whether tritiated polysaccharides had been degraded. The xylan endotransglycosylase reaction product was insensitive to protease treatment as [ $\left.{ }^{3} \mathrm{H}\right]$ incorporation into WAX was identical before and after treatment (data not shown). The xylan endotransglycosylase reaction product was sensitive to fungal xylanase treatment, as 
radioactivity at the origin after paper chromatography was reduced to background levels, showing that the radioactive oligosaccharides were incorporated, presumably by transglycosylation, into high molecular weight WAX.

Fig. 1 shows the incorporation of [ $\left.{ }^{3} \mathrm{H}\right]$-xylo-oligosaccharides into high-molecular weight WAX by separating the products using size exclusion chromatography. The eluate was monitored for total carbohydrate and $\left[{ }^{3} \mathrm{H}\right]$ in reactions with and without active enzyme. The hashed area indicates incorporation of $\left[{ }^{3} \mathrm{H}\right]$ into high-molecular weight polysaccharide, and had a similar shape to $\left[{ }^{3} \mathrm{H}\right]$ incorporated into high-molecular weight xyloglucan by ripe kiwifruit XET (Schröder et al. 1998). Elution profiles at $\mathrm{t}=0$ show that WAX and $\left[{ }^{3} \mathrm{H}\right]$-xylooligosaccharides were well separated under these conditions and that without addition of active enzyme, no $\left[{ }^{3} \mathrm{H}\right]$ label was present in high molecular weight WAX.

Papaya xylan endotransglycosylase did not appear to bind tightly to the cell wall. $\mathrm{A} \mathrm{NaCl}$ concentration of $50 \mathrm{mM}$ in the extraction buffer was sufficient to release the enzyme activity, and a subsequent extraction of the residue with buffer containing $1.3 \mathrm{M} \mathrm{NaCl}$ did not release further activity (data not shown). However, since this may not be the case for xylan endotransglycosylase activity from other tissues or other species, protein was extracted using Mes-NaOH buffer containing 1.3 M NaCl for papaya and all other tissues used subsequently. Xylan endotransglycosylase in papaya extracts was stable at $4 \mathrm{C}$ for at least ten days, and could be frozen at $-80 \mathrm{C}$ and thawed repeatedly with minimal loss of activity (data not shown).

Mcllvaine buffer and a Universal Tribuffer system (Kuo et al. 1985) were used to determine the $\mathrm{pH}$ optimum of xylan endotransglycosylase from papaya fruit. With $\sim 50 \%$ maximal activity at $\mathrm{pH} 4.0$ or 7.0, the enzyme exhibited activity over a relatively broad pH range (Fig. 2a), with two possible optima, the first between $\mathrm{pH} 4.5$ and 5.0 and the second around $\mathrm{pH}$ 6.2 (with slightly less activity). Interestingly, endoxylanase activity from papaya, which was also present in the crude extracts, followed a similar pH pattern (Chen and Paull 2003).

Xylan endotransglycosylase activity was equally efficient within a temperature range of $21^{\circ} \mathrm{C}$ to $55^{\circ} \mathrm{C}$ (Fig. $2 \mathrm{~b}$ ), above which the activity declined. In contrast, the competing endoxylanase activity showed increased efficiency between $21^{\circ} \mathrm{C}$ and $45^{\circ} \mathrm{C}$, above which it declined sharply, confirming observations of Chen and Paull (2003). At temperatures above $60^{\circ} \mathrm{C}$, essentially no endoxylanase activity was detected (Chen and Paull 2003). Endoxylanase activity was only about $30 \%$ of the maximum xylan endotransglycosylase activity at a temperature of $21^{\circ} \mathrm{C}$.

To examine the donor substrate specificity of a crude papaya fruit xylan endotransglycosylase preparation, commercial preparations of WAX and birchwood glucuronoxylan together with dicot fruit cell wall heteroxylans from papaya and tomato were tested (Fig. 3a). Fractions derived from the CTAB precipitate of $1 \mathrm{M}$ or $4 \mathrm{M} \mathrm{KOH}$-soluble extracts 
of papaya and ripe tomato cell walls were both enriched in xylose and uronic acid, indicating the presence of heteroxylans (Table 1). The galactoglucomannan-glucuronoxylan I and II complexes were derived, respectively, from the DMSO-soluble extract of the cell wall (GGM-GX I) and from the CTAB supernatant of the $4 \mathrm{M} \mathrm{KOH}$-soluble extract of tomato (GGM-GX-II) (Prakash et al. 2012). The linkage composition of these fractions is shown in Table 2. Of the heteroxylan donor substrates tested, WAX, the $1 \mathrm{M} \mathrm{KOH}$-soluble preparations from tomato and papaya cell walls, and tomato GGM-GX I were the most efficient donors. Glucuronoxylan from secondary birchwood cell walls was less active, as were the tightly-bound heteroxylans from tomato and papaya cell walls. Partially purified xyloglucan from kiwifruit and highly purified galactoglucomannan from kiwifruit were negligible donor substrates for xylan endotransglycosylase, whereas polygalacturonic acid from citrus showed some donor substrate activity.

To determine the preferences of the papaya enzyme activity for a certain length of acceptor substrate, xylo-oligosaccharides $\left(\left[{ }^{3} \mathrm{H}\right] \mathrm{Xyl}_{2}\right.$-ol up to $\left[{ }^{3} \mathrm{H}\right] \mathrm{Xyl}_{6}$-ol) were assayed for acceptor activity between approximately 100 and $500 \mu \mathrm{M}$, with WAX as the donor substrate. Fig. $3 \mathrm{~b}$ shows that when assayed individually, $\left[{ }^{3} \mathrm{H}\right] \mathrm{Xyl}_{2}$-ol and $\left[{ }^{3} \mathrm{H}\right] \mathrm{Xyl}_{3}$-ol were very weak acceptors, whereas $\left[{ }^{3} \mathrm{H}\right] \mathrm{Xyl}_{4}-\mathrm{ol}$ and $\left[{ }^{3} \mathrm{H}\right] \mathrm{Xyl}_{6}$-ol were moderate acceptors. $\left[{ }^{3} \mathrm{H}\right] \mathrm{Xyl}_{5}-\mathrm{ol}$ was the preferred acceptor for xylan endotransglycosylase, being three-fold more effective than $\left[{ }^{3} \mathrm{H}\right] \mathrm{Xyl}_{4}-\mathrm{ol}$, and 2.5 fold more effective than $\left[{ }^{3} \mathrm{H}\right] \mathrm{Xyl}_{6}-\mathrm{ol}$. Why the longer $\left[{ }^{3} \mathrm{H}\right] \mathrm{Xyl}_{6}-\mathrm{ol}$ is a weaker acceptor than $\left[{ }^{3} \mathrm{H}\right] \mathrm{Xyl}_{5}-\mathrm{ol}$ is unclear, but worthy of further investigation.

Purification of xylan endotransglycosylase from ripe papaya fruit

Xylan endotransglycosylase was purified from papaya fruit 'Rainbow' through a combination of ultrafiltration and cation exchange chromatography on S-Sepharose and MonoS, followed by elution using a salt gradient. The MonoS eluate fractions had xylan endotransglycosylase activity in fractions 15-17, with a maximum in fraction 16 (Fig. 4a). A protein gel of these column fractions showed that most of the protein eluted before fraction 15 (Fig. 4b). From fraction 15 onwards, a few faint protein bands were visible using the colloidal Coomassie stain, indicating that the protein preparation was not pure. A protein band at approximately $32.5 \mathrm{kDa}$ that cross-reacted with antibodies against papaya endoxylanase, an enzyme highly active in ripe papaya, indicated the presence of this protein in the preparation (Fig. 4c). Xylanase assays confirmed co-purification of endoxylanase, with the highest activity occurring in fraction 16 and corresponding to the xylan endotransglycosylase activity elution pattern (Fig. 4a).

The proteins present in fraction 16 were examined using LC-MS analysis to identify tryptic peptide fragments. The analysis yielded 45 peptide fragments that were $100 \%$ identical 
to CpaEXY1 (Table S1), the major xylanase isoform in ripe papaya fruit (Chen and Paull 2003, GenBank accession number AY138986) and a member of glycoside hydrolase family 10 (GH10, http://www.cazy.org/GH10_eukaryota.html). Peptide fragments covering 54\% of the catalytic domain of CpaEXY1 were identified (Fig. 5). No unique fragments corresponding to five other putative xylanase proteins in the papaya genome were detected (Table S2). Multiple peptide fragments corresponding to a thaumatin/osmotin protein (23 fragments), a serine protease $(11)$, and a $(1 \rightarrow 3)$ - $\beta$-glucanase (14) were also observed (Table S1). LC-MS analysis of tryptic digests of the gel-purified immuno-detectable xylanase band at approximately $32.5 \mathrm{kDa}$ also confirmed the presence of the CpaEXY1 protein (data not shown).

From these data we hypothesised that in papaya, xylan endotransglycosylase and endoxylanase activity could be dual activities of CpaEXY1. However, it was not possible to exclude that an additional protein that possessed xylan endotransglycosylase activity was also present at a very low concentration. To investigate this further, the full-length open reading frame of CpaEXY1 was transiently over-expressed in $N$. benthamiana leaves using a hybrid tobacco mosaic virus / tomato mosaic virus vector (TTOSA1-XYL). SDS-PAGE and western blot analyses using an antibody raised against the CpaEXY1 catalytic domain revealed a doublet of 28-30 kDa (Fig. S1). This was smaller in size than the native processed immuno-detectable endo-xylanase protein from ripe papaya fruit, and showed that the CpaEXY1 protein was processed in a slightly different way in $N$. benthamiana than it was in papaya. No immunodetectable protein bands were visible in extracts from leaves transfected with the empty vector.

Protein extracts from transfected $N$. benthamiana leaves with the viral vector TTOSA1XYL were tested for xylanase and xylan endotransglycosylase activities and compared with those from leaves transfected with the empty TTOSA1 vector. The extract containing recombinant CpaEXY1 protein had both activities (Table 3), demonstrating that papaya CpaEXY1 is a single enzyme with both xylan endotransglycosylase and xylanase activities. After either extended assay times or in assays that contained protein concentrations above those stated in Table 3, the hydrolysis activity of endoxylanase caused decreasing transglycosylation activity by hydrolysing both donor and acceptor substrates (data not shown).

Kinetics of transglycosylase and hydrolase reactions of papaya endoxylanase

Due to the incorrect processing of the recombinant protein in $N$. benthamiana, it was inappropriate to use this for kinetic analysis of these activities. Instead we focussed on kinetic analysis of purified native protein from papaya with the assumption that a single protein possessed two activities. Endotransglycosylase and hydrolase reactions were carried out under 
identical conditions, with the only difference being the presence of $\left[{ }^{3} \mathrm{H}\right] \mathrm{Xyl}_{5}-\mathrm{ol}$ as acceptor in the endotransglycosylase reaction.

The hydrolysis reaction was linear up to $125 \mathrm{~min}$ using 0.2 and $0.4 \%$ (w/v) WAX, respectively (Fig. 6a). The doubling of the polysaccharide (donor) concentration approximately doubled the hydrolysis rate. Transglycosylation reactions were carried out using increasing acceptor concentrations at a constant donor concentration of $0.2 \%(\mathrm{w} / \mathrm{v}) \mathrm{WAX}$. Doubling the acceptor concentration from 234 to $467 \mu \mathrm{M}\left[{ }^{3} \mathrm{H}\right] \mathrm{Xyl}_{5}-\mathrm{ol}$ resulted in an almost doubling of the transglycosylation rate (Fig. 6b). An acceptor concentration of $117 \mu \mathrm{M}$ resulted in a very low reaction rate, indicating that optimal acceptor concentrations were above this concentration. Increasing the donor concentration from $0.1 \%$ to $0.4 \%(\mathrm{w} / \mathrm{v})$ at a constant acceptor concentration of $234 \mu \mathrm{M}$ increased the endotransglycosylase reaction (Fig. 6c). In Fig. 6a and b, the transglycosylation and hydrolysis rates are directly comparable. At a donor concentration of $0.2 \%(\mathrm{w} / \mathrm{v}) \mathrm{WAX}$ in both assays, the rate of hydrolysis was between 2 times (using acceptor concentration of $467 \mu \mathrm{M}$ for transglycosylation) to 4 times (using acceptor concentration of 234 $\mu \mathrm{M}$ for transglycosylation) higher than the transglycosylation rate under identical conditions.

Xylan endotransglycosylase activity is found in a range of fruit, vegetable and cereal tissues

Xylan endotransglycosylase and xylanase activities were assayed in ripening papaya cultivars, other fruit and vegetable tissues, and in imbibed seeds and growing seedlings of monocots, to determine whether the enzyme played a role in either fruit ripening, mobilisation of seed storage xylans or cell expansion during growth. Tissues were chosen on the basis that they either had high heteroxylan content in the cell walls or were rich in xylanase activity (Brummell and Schröder 2009).

Fruit from a range of papaya cultivars was examined at different ripening stages to investigate whether xylan endotransglycosylase and xylanase activities showed a similar pattern during softening or whether either of the activities was predominant (Fig. 7a). Overall, the papaya cultivars showed different amounts of xylan endotransglycosylase and xylanase activity. In 'Sunset', 'PPY' and 'Sunrise', where different ripening stages were examined, both activities increased during ripening, except for 'Sunrise', where xylan endotransglycosylase activity did not increase between the 50\% and 100\% ripe stages. In 'PPY' and 'Sunrise', xylan endotransglycosylase activity was lower than in 'Sunset' and 'Rainbow'; here, xylanase activity seemed the predominant reaction.

Xylan endotransglycosylase activity was detected in protein extracts prepared from a range of other fruit and vegetable tissues (Fig. 7b), although in all cases the activity was much less than in ripe papaya fruit. Of these, xylan endotransglycosylase activity was found in celery 
stalks, in flesh of ripe fruit of avocado and pineapple, as well as in apple peel protein extracts. Negligible activity was found in ripe tomato skin and outer pericarp, kiwifruit outer pericarp, flesh of European pear and Ya pear, and lettuce leaves (data not shown). Except for avocado, none of the tissues assayed showed detectable xylanase activity.

Xylan endotransglycosylase and xylanase activities were determined in extracts of imbibed germinating seeds and in rapidly growing seedlings of barley, oat, maize and wheat. Xylan endotransglycosylase activity was present in rapidly growing seedlings of all four species tested, whilst xylanase activity was barely detectable (Fig. 7c). In imbibed seeds, xylan endotransglycosylase and xylanase activities were found in oat and barley, and at much lower amounts in maize and wheat. The low xylanase and xylan endotransglycosylase activities could be due to either unsuitable $\mathrm{pH}$ or substrate conditions in the assay or the presence of endogenous xylanase inhibitors (Biely et al. 2008; Simpson et al. 2003). Although these inhibitors have so far been shown to act only as a defence mechanism against microbial pathogens, suggestions have been made that they may also have a potential role in the regulation of plant xylanases (Simpson et al. 2003).

\section{Discussion}

The present study has established that xylan endotransglycosylase activity is present in primary cell walls and is able to carry out transglycosylation reactions on a range of heteroxylan polysaccharides. Assaying the enzyme activity by its ability to attach the reducing ends of xylan donors to the non-reducing ends of tritiated xylan oligosaccharide acceptors, we found the widespread existence of xylan endotransglycosylase activity in both monocotyledonous and dicotyledonous plants, at different developmental stages. The highest activity was present in ripening papaya fruit. Here, the activity could be attributed to papaya endoxylanase CpaEXY1. Together with XET and mannan endotransglycosylase, xylan endotransglycosylase completes the suite of enzymes necessary for the incorporation of hemicelluloses into the developing plant cell wall.

Native papaya xylan endotransglycosylase used a wide range of heteroxylans from different sources as donor, although highest activity was found with WAX, suggesting that the enzyme preferentially used a more highly substituted xylan backbone rather than a lesssubstituted one such as birchwood 4-O-methyl-D-glucuronoxylan. Differences in donor molecular weight could also conceivably play a role in substrate preference. The donor polysaccharide concentrations used in the enzyme assays were similar to those used in assays for mannan endotransglycosylase or XET activity (Fry et al. 1992; Schröder et al. 2004). A 
variation in donor preference was also found amongst the highly substituted substrates purified from tomato and papaya fruit primary cell walls. The loosely bound heteroxylans purified from $1 \mathrm{M} \mathrm{KOH}$-soluble cell wall polysaccharides were better donor substrates than the tightly bound 4 M KOH-derived polysaccharides, and the DMSO-soluble very loosely bound GGM-GX I from tomato was much better than the firmly bound GGM-GX II purified from a $4 \mathrm{M} \mathrm{KOH-soluble}$ extract. This may be because of the relatively higher xylose contents of these preparations.

Papaya xylan endotransglycosylase and endoxylanase activities had similar $\mathrm{pH}$ optima, but the temperature sensitivity of the reactions was markedly different. This may indicate that papaya endoxylanase and xylan endotransglycosylase activity are due to either different but related proteins (possibly of the -xylanase family) or to different isoforms of CpaEXY1. The papaya genome contains a xylanase gene family of up to six members (Ming et al. 2008; Table S2), three of which possess a signal sequence targeting the mature protein to the apoplast. However, tryptic digests of the highly purified protein fraction from MonoS chromatography yielded only xylanase fragments homologous to CpaEXY1 and not other putative xylanases, showing that isoforms of CpaEXY1 were the most abundant protein in the preparation.

Papaya fruit endoxylanase, like all other plant xylanases, undergoes extensive posttranslational modifications (Chen and Paull 2003). The CpaEXY1 gene encodes a 65 kDa primary translation product, and after cleavage of a signal peptide directing the protein to the apoplast, and further cleavage of C-terminal and N-terminal domains, an active catalytic domain of 32.5 $\mathrm{kDa}$ remains. Although xylanases are typically found as small gene families, xylanase isoforms generated by differential proteolytic processing seem to be common. In the aleurone layer of cereals, processing produced many xylanase intermediates (Caspers et al. 2001), and active enzymes of molecular masses of 55 and $30 \mathrm{kDa}$ in wheat (Cleemput et al. 1997), and $29 \mathrm{kDa}$ (Dashek and Chrispeels 1977) and 41 kDa (Banik et al. 1996) in barley have been reported. A similar situation seems to exist in papaya, with different isozymes being created by differential processing of CpaEXY1. Two-dimensional protein gel electrophoresis of proteins isolated from ripe mesocarp of 'PPY' papaya fruit followed by immuno-staining of the protein gel blot using an antibody against papaya xylanase showed multiple cross-reacting spots in the 25 to $33 \mathrm{kDa}$ size range and with pI from 6.0 to 7.0 (Fig. S2). Of these spots, three were close to the predicted size of the catalytic subunit of $32.5 \mathrm{kDa}$. The lack of correlation between the relative xylan endotransglycosylase and endoxylanase activities in germinating cereal grains and seedlings also points to the possibility that the two activities are either due to separate proteins or to additional isoforms resulting from differential processing of the same protein. The detection of xylan endotransglycosylase activity in a range of species and tissues in which endoxylanase activity was undetectable also suggests that multiple proteins may be involved. 
XTH and endo- $\beta$-mannanase families possess multiple isoforms with a range of endotransglycosylase and hydrolase activities. Most Arabidopsis XTHs are strict XETs, and only two out of the $>30$ members of this gene family are predicted to show xyloglucanase activity (Baumann et al. 2007). Molecular modelling and mutagenesis have shown that proteins with XET and xyloglucanase activities are very similar, and that xyloglucanase activity is at least in part due to the presence of a small loop in the protein that is absent in endotransglycosylases (Baumann et al 2007). However, XTHs belong to GH16 and adopt a -jellyroll conformation (Baumann et al. 2007), whereas plant endo- -xylanases including CpaEXY1 from papaya belong to GH10 and fold into a ( / )8-barrel (Pell et al. 2004), and so are structurally more related to the endo- -mannanases of GH5 (Bourgault et al. 2005). All of these GH families use a double displacement/retaining mechanism of glycosyl transfer, which potentially allows for endotransglycosylase reactions (Roberge et al. 1999; Moreau et al. 1994; Biely et al. 1991; Sinnott 1990).

Determining the relative rates of transglycosylation and hydrolysis of native CpaEXY1 in vitro showed that the hydrolysis rate was 2 to 4 times higher than the transglycosylation rate. However, lower endotransglycosylase activity does not necessarily mean that the endotransglycosylase reaction is insignificant in biological terms. It is also important to recognise that in vitro quantitative and qualitative studies of enzyme activity may not necessarily reflect what is happening in vivo. The activity of cell wall enzymes can differ in free solution compared to in the apoplast where, due to either the pore size of the cell wall or binding to cell wall polysaccharides, protein mobility or action may be restricted. Cell wall conditions of water concentration, ionic milieu, and local $\mathrm{pH}$ are also difficult to replicate exactly in vitro. For example, endo-ß-mannanase in ripe tomato fruit exhibits both mannanase and mannan endotransglycosylase activities in vitro; however, in muro it is possible that if the enzyme acts at all, it acts as an endotransglycosylase since mannans do not change in size during tomato ripening (Prakash et al. 2012). To gain a better insight into xylanase and endo- $\beta$ mannanase enzymes, assays aimed at investigating their endotransglycosylase activity in muro must be carried out, as outlined for XTH by Fry (2004). Those plant species which exhibited comparatively high endotransglycosylase and low hydrolase activity would make ideal sources in which true transglycosylases might be found.

Endoxylanase activity has been identified in several plant species and tissues. In cereal grains, xylanase hydrolyses primary cell wall heteroxylans for the mobilisation of endosperm nutrients during germination (Caspers et al. 2001). In maize, xylanase activity is involved in the lysis of the tapetum-containing anther wall at pollen maturation (Bih et al. 1999) and the hydrolysis of the stigma surface for pollen tube penetration (Wu et al. 2002), and in Arabidopsis 
is associated with secondary cell wall metabolism during vascular bundle development (Suzuki et al. 2002). In ripe papaya fruit, the activities of both endoxylanase (Paull and Chen 1983) and xylan endotransglycosylase (Fig. 6a) increased as fruit softened during ripening. It has been shown that the molecular weight of hemicelluloses declines during softening (Paull et al. 1999), although a specific examination of xylans has not been made. Xylan endotransglycosylase activity was also found in ripe fruit of avocado, banana, pineapple, and apple. We observed considerable endoxylanase activity in extracts of imbibed seeds of oat and barley, tissues that are rich in storage heteroxylans. Endoxylanase activity was much lower in growing seedlings, although both tissues also exhibited xylan endotransglycosylase activity, at least in vitro. These activities could of course be due to the presence of different proteins with specific either xylan endotransglycosylase or endoxylanase activity. In growing seedlings, xylan

endotransglycosylase activity may be acting to reorganise xylans in the cell wall to support wall modifications. Evidence in support of a xylan endotransglycosylase reaction during rapid growth is reported in maize suspension cultures, where the molecular mass of xylans increased dramatically in the first hours after deposition into the cell wall (Kerr and Fry 2003). The incorporation of new xylan polymers into the expanding wall via transxylosylation may therefore be a major function for xylan endotransglycosylase enzymes in young tissues. Overall, the discovery of a xylan endotransglycosylase activity is consistent with recent reports (Franková and Fry 2011,2012) that transglycosylation may be a much more common feature of primary cell wall metabolism than previously appreciated.

\section{Electronic Supplemetary Material}

The following materials are available in the online version of this article:

Table S1 Peptide fragments in fraction 16 eluted from the MonoS column

Table S2 Predicted xylanase proteins and open reading frames in the papaya genome

Fig. S1 Analysis of the recombinant protein products produced in Nicotiana benthamiana leaves using viral vector TTOSA1-XYL

Fig. S2 2D-gel electrophoresis and gel blot of papaya fruit proteins

\section{Acknowledgements}

We thank Erin O'Donoghue, William Laing and Robert Schaffer for comments on the manuscript. We are indebted to Lionel M. Hill (John Innes Centre, Norwich, England) for his advice with the enzyme kinetics. We also thank Cherie Walsh, ARC Centre of Excellence in Plant Cell Walls, The University of Melbourne, for technical assistance with cell wall methylation analyses. Antony 
Bacic acknowledges the support of the ARC Centre of Excellence in Plant Cell Walls. This project was funded by the Ministry of Science and Innovation New Zealand (contract C11X1007). 


\section{References}

Ahmed AER, Labavitch JM (1977) A simplified method for accurate determination of cell wall uronide content. J Food Biochem 1:361-365

Ait-Mohand F, Farkaš V (2006) Screening for hetero-transglycosylating activities in extracts from nasturtium (Tropaeolum majus). Carbohydr Res 341:577-581

Albersheim P, Nevins DJ, English PD, Karr A (1967) A method for the analysis of sugars in plant cell-wall polysaccharides by gas-liquid chromatography. Carbohydr Res 5:340-345

Banik M, Garrett TP, Fincher GB (1996) Molecular cloning of cDNAs encoding (1-->4)-beta-xylan endohydrolases from the aleurone layer of germinated barley (Hordeum vulgare). Plant Mol. Biol. 31:1163-1172

Baumann MJ, Eklöf JM, Michel G, Kallas ÅM, Teeri TT, Czjzek M, Brumer H (2007) Structural evidence for the evolution of xyloglucanase activity from xyloglucan endotransglycosylases: biological implications for cell wall metabolism. Plant Cell 19: 19471963

Bewley JD, Banik M, Bourgault R, Feurtado JA, Toorop P, Hilhorst HWM (2000) Endo-ßmannanase activity increases in the skin and outer pericarp of tomato fruits during ripeni. J Exp Bot 51:529-538

Bewley JD, Burton RA, Morohashi Y, Fincher GB (1997) Molecular cloning of a cDNA encoding a (1 4)-ß-mannan endohydrolase from the seeds of germinated tomato (Lycopersicon esculentum). Planta 203:454-459

Biely P, Leathers TD, Cziszarova M, Vrŝanská M, Cotta MA (2008) Endo-beta-1,4-xylanase inhibitors in leaves and roots of germinated maize. J Cereal Sci 48:27-32

Biely P, Vrŝanská M, Claeyssens M (1991) The endo-1,4- $\beta$-glucanase from Trichoderma reesei. Action on $\beta$-1,4-oligomers and polymers derived from D-glucose and D-xylose. Eur J Biochem 200:157-163

Bih FY, Wu SSH, Ratnayake C, Walling LL, Nothnagel EA, Huang AHC (1999) The predominant protein on the surface of maize pollen is an endoxylanase synthesized by a tapetum mRNA with a long 5' leader. J Biol Chem 274:22884-22894

Blumenkrantz N, Asboe-Hansen G (1973) New method for quantitative determination of uronic acids. Anal Biochem 54:484-489

Bourgault R, Oakley AJ, Bewley JD, Wilce MCJ (2005) Three-dimensional structure of (1,4)- $\beta$-Dmannan mannanohydrolase from tomato fruit. Protein Sci 14:1233-1241

Brummell DA, Schröder R (2009) Xylan metabolism in primary cell walls. New Zealand J Forestry Sci 39:125-143

Carpita NC (1983) Hemicellulosic polymers of cell walls of Zea coleoptiles. Plant Physiol 72:515521

Caspers MP, Lok F, Sinjorgo KM, Van Zeijl MJ, Nielsen KA, Cameron-Mills V (2001) Synthesis, processing and export of cytoplasmic endo-beta-1,4-xylanase from barley aleurone during germination. Plant J 26:191-204 
Chen NJ, Paull RE (2003) Endoxylanase expressed during papaya fruit ripening: purification, cloning and characterization. Funct Plant Biol 30:433-441

Cleemput G, van Laere K, Hessing M, van Leuven F, Torrekens S, Delcour JA (1997) Identification and characterization of a novel arabinoxylanase from wheat. Plant Physiol 115:619-627

Coulombel C, Clermont S, Foglietti M-J, Percheron F (1981) Transglycosylation reactions catalysed by two -mannanases. Biochem J 195:333-335

Dashek WV, Chrispeels MJ (1977) Gibberellic acid induced synthesis and release of cell-walldegrading endoxylanase by isolated aleurone layers of barley. Planta 134:251-256

Edwards M, Dea ICM, Bulpin PV, Reid JSG (1986) Purification and properties of a novel xyloglucan-specific endo-(1 4)-ß-D-glucanase from germinated nasturtium seeds (Tropaeolum majus L). J Biol Chem 261:9489-9494

Eklöf JM, Brumer H (2010) The XTH gene family: an update on enzyme structure, function, and phylogeny in xyloglucan remodeling. Plant Physiol 153:456-466

Farkaš V, Sulova Z, Stratilova E, Hanna R, Maclachlan G (1992) Cleavage of xyloglucan by nasturtium seed xyloglucanase and transglycosylation to xyloglucan subunit oligosaccharides. Arch Biochem Biophys 298:365-370

Franková L, Fry SC (2011) Phylogenetic variation in glycosidases and glycanases acting on plant cell wall polysaccharides, and the detection of transglycosidase and trans- $\beta$-xylanase activities. Plant J 67:662-681

Franková L, Fry SC (2012) Trans- $\alpha$-xylosidase and trans-ß-galactosidase activities, widespread in plants, modify and stabilize xyloglucan structures. Plant J 71:45-60

Fry SC (2004) Primary cell wall metabolism: tracking the careers of wall polymers in living plant cells. New Phytol 161:641-675

Fry SC, Mohler KE, Nesselrode BHWA, Franková L (2008) Mixed-linkage $\beta$-glucan : xyloglucan endotransglucosylase, a novel wall-remodelling enzyme from Equisetum (horsetails) and charophytic algae. Plant J 55:240-252

Fry SC, Smith RC, Renwick KF, Martin DJ, Hodge SK, Matthews KJ (1992) Xyloglucan endotransglycosylase, a new cell wall-loosening enzyme activity from plants. Biochem J 282:821-828

Hrmova M, Farkaš V, Lahnstein J, Fincher GB (2007) A barley xyloglucan xyloglucosyl transferase covalently links xyloglucan, cellulosic substrates, and (1,3;1,4)- $\beta$-D-glucans. J Biol Chem 282:12951-12962

Jimenez CR, Huang L, Qiu Y, Burlingame AL (2003) In-gel digestion of proteins for MALDI-MS fingerprint mapping,. In JE Coligan, Dunn BM, Ploegh HL, Speicher DW, Wingfield PT (ed.), Current protocols in protein science. Wiley, Hoboken, N.J., pp. 16.4.1-16.4.5

Kerr EM, Fry SC (2003) Pre-formed xyloglucans and xylans increase in molecular weight in three distinct compartments of a maize cell-suspension culture. Planta 217:327-339

Kumagai MH, Donson J, Della-Cioppa G, Grill LK (2000) Rapid, high-level expression of glycosylated rice -amylase in transfected plants by an RNA viral vector. Gene 245:169-174 
Kuo LC, Herzberg W, Lipscomb WN (1985) Substrate specificity and protonation state of ornithine transcarbamoylase as determined by pH studies. Biochemistry 24:4754-4761

Lever M (1972) A new reaction for colorimetric determination of carbohydrates. Anal Biochem 47:273-279

Maclachlan G, Brady C (1994) Endo-1,4- $\beta$-glucanase, xyloglucanase, and xyloglucan endotransglycosylase activities versus potential substrates in ripening tomatoes. Plant Physiol 105:963-974

Manenoi A, Paull RE (2007) Papaya fruit softening, endoxylanase gene expression, protein and activity. Physiol Plant 131:470-480

Marraccini P, Rogers WJ, Allard C, André M-L, Caillet V, Lacoste N, Lausanne F, Michaux S (2001) Molecular and biochemical characterization of endo- -mannanases from germinating coffee (Coffea arabica) grains. Planta 213:296-308

Melton LD, Smith BG, Ibrahim R, Schröder R (2009) Mannans in primary and secondary plant cell walls. New Zealand J Forestry Sci 38:53-160

Ming R et al. (2008) The draft genome of the transgenic tropical fruit tree papaya (Carica papaya Linnaeus). Nature 452:991-996

Moreau A, Shareck F, Kluepfel D, Morosoli R (1994) Alteration of the cleavage mode and the transglycosylation reactions of the xylanase A of Streptomyces lividans 1326 by sitedirected mutagenesis of the Asn173 residue. Eur J Biochem 219:261-266

Nieuwenhuizen NJ, Beuning LL, Sutherland PW, Sharma NN, Cooney JM, Bieleski LRF, Schröder R, MacRae EA, Atkinson RG (2007) Identification and characterization of acidic and novel basic forms of actinidin, the highly abundant cysteine protease from kiwifruit. Funct Plant Biol 34: 946-961

Nishitani K, Tominaga R (1992) Endo-xyloglucan transferase, a novel class of glycosyltransferase that catalyzes transfer of a segment of xyloglucan molecule to another xyloglucan molecule. J Biol Chem 267:21058-21064

Park YB, Cosgrove DJ (2012) A revised architecture of primary cell walls based on biomechanical changes induced by substrate-specific endoglucanases. Plant Physiol 158:1933-1943

Paull RE, Chen NJ (1983) Postharvest variation in cell wall-degrading enzymes of papaya (Carica papaya L.) during fruit ripening. Plant Physiol 72:382-385

Paull RE, Gross K, Qiu YX (1999) Changes in papaya cell walls during fruit ripening. Postharvest Biol Technol 16:79-89

Pell G, Taylor EJ, Gloster TM, Turkenburg JP, Fontes CMGA, Ferreira LMA, Nagy T, Clark SJ, Davies GJ, Gilbert HJ (2004) The mechanisms by which family 10 glycoside hydrolases bind decorated substrates. J Biol Chem 279:9597-9606

Pettolino FA, Walsh C, Fincher GB, Bacic A (2012) Determining the polysaccharide composition of plant cell walls. Nature Protocols 7:1590-1607

Prakash R, Johnston SL, Boldingh HL, Redgwell RJ, Atkinson RG, Melton LD, Brummell DA, Schröder R (2012) Mannans in tomato fruit are not depolymerised during ripening despite the presence of endo- $\beta$-mannanase. J Plant Physiol 169:1125-1133 
Roberge M, Shareck F, Morosoli R, Kluepfel D, Dupont C (1999) Characterisation of active-site aromatic residues in xylanase A from Streptomyces lividans. Protein Engineering 12:251257

Schröder R, Atkinson RG, Langenkämper G, Redgwell RJ (1998) Biochemical and molecular characterisation of xyloglucan endotransglycosylase from ripe kiwifruit. Planta 204:242251

Schröder R, Atkinson RG, Redgwell RJ (2009) Re-interpreting the role of endo- $\beta$-mannanases as mannan endotransglycosylase/hydrolases in the plant cell wall. Botanical Briefing. Ann Bot 104:197-204

Schröder R, Johnston SL, Prakash R, Chen NJ, Kumagai MH, Paull RE, Turano HM, Cooney J, Atkinson RG, Brummell DA (2010) Xylan endotransglycosylase, a novel enzyme activity in primary cell walls. T80. XII Cell Wall Meeting, Porto, Portugal, July 2010

Schröder R, Nicolas P, Vincent SJF, Fischer M, Reymond S, Redgwell RJ (2001) Purification and characterisation of a galactoglucomannan from ripe kiwifruit (Actinidia deliciosa). Carbohydr Res 331:291-306

Schröder R, Wegrzyn TF, Bolitho KM, Redgwell RJ (2004) Mannan transglycosylase: A novel enzyme activity in cell walls of higher plants. Planta 219:590-600

Schröder R, Wegrzyn TF, Sharma NN, Atkinson RG (2006) LeMAN4 endo- $\beta$-mannanase from ripe tomato fruit has dual enzyme activity and can act as a mannan transglycosylase and hydrolase. Planta 224:1091-1102

Simpson DJ, Fincher GB, Huang AHC, Cameron-Mills V (2003) Structure and function of cereal and related higher plant (1 $\rightarrow 4)$ - $\beta$-xylan endohydrolases. J Cereal Sci 37:111-127

Sinnott ML (1990) Catalytic mechanisms of enzymatic glycosyl transfer. Chem. Rev. 90:11711202

Suzuki M, Kato A, Nagata N, Komeda Y (2002) A xylanase, AtXyn1, is predominantly expressed in vascular bundles, and four putative xylanase genes were identified in the Arabidopsis thaliana genome. Plant Cell Physiol 43:759-767

Whitney SEC, Brigham JE, Darke AH, Reid JSG, Gidley MJ (1998) Structural aspects of the interaction of mannan-based polysaccharides with bacterial cellulose. Carbohydr Res 307:299-309

Wu SSH, Suen DF, Chang HC, Huang AHC (2002), Maize tapetum xylanase is synthesized as a precursor, processed and activated by a serine protease, and deposited on the pollen. J Biol Chem 277:49055-49064

Yokoyama R, Nishitani K (2004) Genomic basis for cell-wall diversity in plants. A comparative approach to gene families in rice and Arabidopsis. Plant Cell Physiol 46:1111-1121 


\section{Figure legends}

Fig. 1 Incorporation of [ $\left.{ }^{3} \mathrm{H}\right]$ xylo-oligosaccharides (OS) into high-molecular weight wheat arabinoxylan (WAX) at $\mathrm{t}=0$ without addition of papaya extract (WAX, $\mathrm{t}=0$ ) and after 60 min with extract (Product). Crude papaya extract $(100 \mu \mathrm{L})$ was incubated with $\left[{ }^{3} \mathrm{H}\right]$ xylo-oligosaccharide mixture $(0.04 \% \mathrm{w} / \mathrm{v})$, WAX $(0.25 \% \mathrm{w} / \mathrm{v})$, and $0.2 \mathrm{M}$ Mes buffer, $\mathrm{pH} 5.5$, for $1 \mathrm{~h}$ at $21^{\circ} \mathrm{C}$. For the $\mathrm{t}=0$ reactions, WAX and the $\left[{ }^{3} \mathrm{H}\right]$ xylo-oligosaccharide mixture were incubated for $1 \mathrm{~h}$ without the addition of enzyme. Products were separated by size exclusion chromatography on Sepharose S300 (75 x $1.5 \mathrm{~cm}$; eluent $0.05 \mathrm{M} \mathrm{Na}$-acetate pH 6.0, $0.125 \mathrm{M} \mathrm{NaCl}, 0.05 \%$ chlorobutanol; fraction size $20 \mathrm{~min}$, flow rate $\sim 6 \mathrm{~mL} \mathrm{~h}^{-1}$ ). Elution profiles were monitored as total carbohydrates (TC) using the phenol sulphuric assay. $\left[{ }^{3} \mathrm{H}\right]$ label was measured using scintillation counting with aqueous scintillant at $\mathrm{t}=0$ ( ${ }^{3} \mathrm{H}$ Xylan OS) and after $60 \mathrm{~min}$ with papaya extract (Product ${ }^{3} \mathrm{H}$ label). The hashed area indicates $\left[{ }^{3} \mathrm{H}\right]$ label incorporation into highmolecular weight polymeric product. Maximum radioactivity $(728 \mathrm{kBq})$ was eluted at approximately $115 \mathrm{~mL}$ elution volume, consisting of unincorporated [ $\left.{ }^{3} \mathrm{H}\right]$ xylo-oligosaccharides.

Fig. $2 \mathrm{pH}$ and temperature optima of xylan endotransglycosylase from crude papaya fruit protein extract. a pH optimum was assessed using McIlvaine buffer (0.1 M Na citrate and $0.2 \mathrm{M}$ $\left.\mathrm{NaH}_{2} \mathrm{PO}_{4}\right)$ and Universal Tribuffer $(0.05 \mathrm{M}$ diethanolamine, $0.1 \mathrm{M}$ Mes and $0.05 \mathrm{M}$ 4ethylmorpholine), with $0.25 \%$ wheat arabinoxylan and $0.04 \%\left[{ }^{3} \mathrm{H}\right]$ xylo-oligosaccharide mixture as substrates. Reactions were carried out at $21^{\circ} \mathrm{C}$ for $1 \mathrm{~h}$ at the $\mathrm{pH}$ indicated. $\mathbf{b}$ Temperature optimum was determined using the same substrate concentrations as described above, with 10 $\mu \mathrm{L}$ of extract in a reaction volume of $20 \mu \mathrm{L}$ containing $30 \mathrm{mM}$ Mes buffer, $\mathrm{pH}$ 5.5. For comparison, the temperature optimum of papaya xylanase is also shown (determined using xylan-RBB in the appropriate buffer as described in Materials and Methods).

Endotransglycosylase and hydrolase reactions were incubated at the temperature indicated for $1 \mathrm{~h}$. Data are expressed as \% maximum activity, and were derived from the means of two triplicated experiments SD.

Fig. 3 Donor and acceptor substrate preferences of xylan endotransglycosylase from crude papaya fruit protein extract. a Donor substrate specificity was determined using a mixture of $\left[{ }^{3} \mathrm{H}\right]$ xylo-oligosaccharides as acceptors and a range of polysaccharide substrates as donors: WAX (wheat arabinoxylan), birchwood xylan, heteroxylan-enriched cell wall fractions obtained by 
CTAB precipitation of $1 \mathrm{M}$ and $4 \mathrm{M} \mathrm{KOH}$-soluble extracts of tomato or papaya fruit cell walls, galactoglucomannan-glucuronoxylan I and II (GGM-GX I, II) from ripe tomato cell walls, kiwifruit xyloglucan, citrus polygalacturonic acid (PGA), kiwifruit galactoglucomannan (GGM). b Acceptor substrate specificity was determined using WAX as donor and the [3 $\mathrm{H}]$ xylooligosaccharide indicated as acceptor. The acceptors were assayed between approximately 100 and $500 \mu \mathrm{M}$ for $1 \mathrm{~h}$. Experiments were carried out 2-3 times, and values are means of a typical, triplicated experiment SD.

Fig. 4 Purification of xylan transglycosylase and xylanase activities from 'Rainbow' papaya fruit using ion exchange chromatography. a xylan endotransglycosylase and xylanase activity of MonoS column fractions. Transglycosylase assays were carried out using WAX as donor and the tritiated xylo-oligosaccharide mixture as acceptors for $1 \mathrm{~h}$ at $21^{\circ} \mathrm{C}$, and hydrolase assays using RBB-xylan, for $1 \mathrm{~h}$ at $37^{\circ} \mathrm{C}$. Xylan endotransglycosylase activities are given as Bq incorporated per kBq provided per $\mu \mathrm{g}$ protein per $\mathrm{h}$, and xylanase as $A_{595}$ per $\mu \mathrm{g}$ protein per $\mathrm{h}$. b Protein gel of the column fractions, stained with colloidal Coomassie Blue. c Protein gel blot reacted with antixylanase antiserum. The arrows indicate the predicted size of the mature protein $(\sim 32.5 \mathrm{kDa})$.

Fig. 5 The amino acid sequence of papaya endoxylanase CpaEXY1 (GenBank accession number AY138986) with the predicted signal sequence (1-28; double underlined) and predicted carbohydrate binding module (51-182; underlined). The two short regions boxed in grey (232235 and 518-520) were the predicted sites of proteolysis to produce the mature protein described in Chen and Paull (2003). Bolded residues were part of fragments obtained by LC-MS analysis of fraction 16 eluted from the MonoS column (Table S1).

Fig. 6 Kinetics of the xylan endotransglycosylase and xylanase reaction. a Xylanase activity at two different WAX donor concentrations. Xylanase assays were performed by assaying reducing termini using the PAHBAH assay. $\mathbf{b}$ Xylan transglycosylase activity at two acceptor concentrations, $234 \mu \mathrm{M}$ and $467 \mu \mathrm{M}\left[{ }^{3} \mathrm{H}\right] \mathrm{Xyl}_{5}$-ol, using 0.2\% WAX as donor. c Xylan transglycosylase activity at donor concentrations from 0.1 to $0.4 \%(\mathrm{w} / \mathrm{v}$ ) WAX using $234 \mu \mathrm{M}$ $\left[{ }^{3} \mathrm{H}\right] \mathrm{Xyl}_{5}-\mathrm{ol}$ as acceptor, assayed for $30 \mathrm{~min}$. Experiments were carried out three times using highly purified CpaEXY1 from ripe papaya fruit; shown are the results of a typical triplicated experiment $\pm \mathrm{SD}$. WAX donor substrate concentrations are given in $\%$ as the molecular weight of 
the polysaccharide is too disperse to be calculated in molarities (see elution profile WAX at $t=0$ in Fig. 1).

Fig. 7 Xylan endotransglycosylase and xylanase activities in crude protein extracts of various tissues and species. a Comparison of activities between four cultivars of ripening papaya fruit at different ripening stages. $\mathbf{b}$ Activities in a range of fruit and vegetable tissues. $\mathbf{c}$ Activities in imbibed cereal grains and in the corresponding young growing seedlings. Values are means of two triplicated experiments SD. 


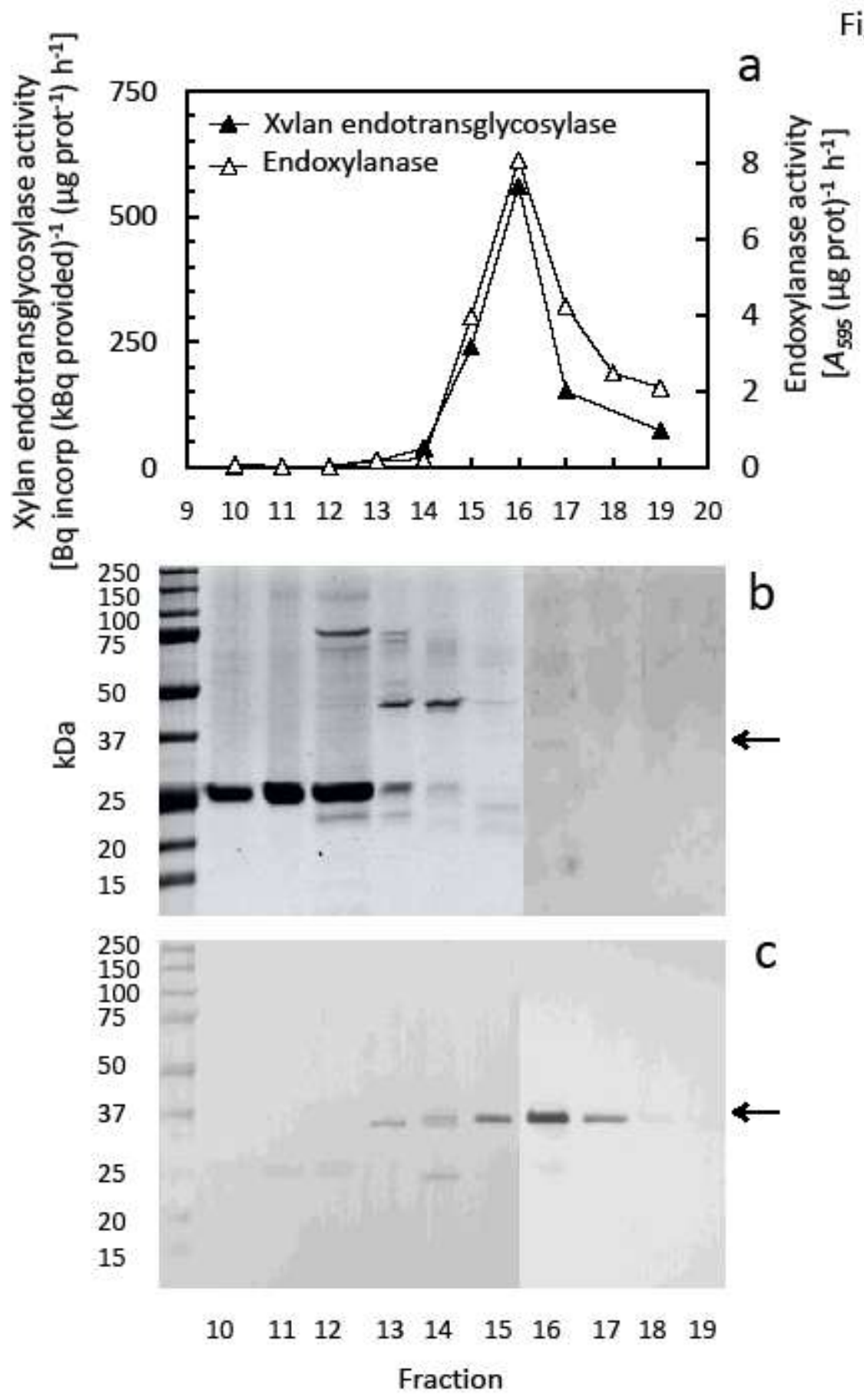

Figure 5

1 MKLGEKNLQF YFLLVLPYAL LFPGLETNAL SYDYTASIQC LENPQKAQYG

51 GGIITNPELN QGLKGWSTFG DAKIQHRVAG SNSFIVAHTR SQPHDSVSQT

101 LYLQSNKLYT FSAWIRVSEG KTPVKAIFKT KSGYKYAGAV VAESNCWSML

151 KGGLTVDASG PAELYFETDN TSVEIWIDSI SLQPFTQQEW KSHQDQSIKK

201 IRKKNVRIQA VDKLGNPLPN TTVSISPKKI GFPFGCAINR NILNNNAYQS

251 WFSSRFTVTT FENEMKWAST EPSQGHEDYS TADAMVQFAK KNGIAIRGHN 


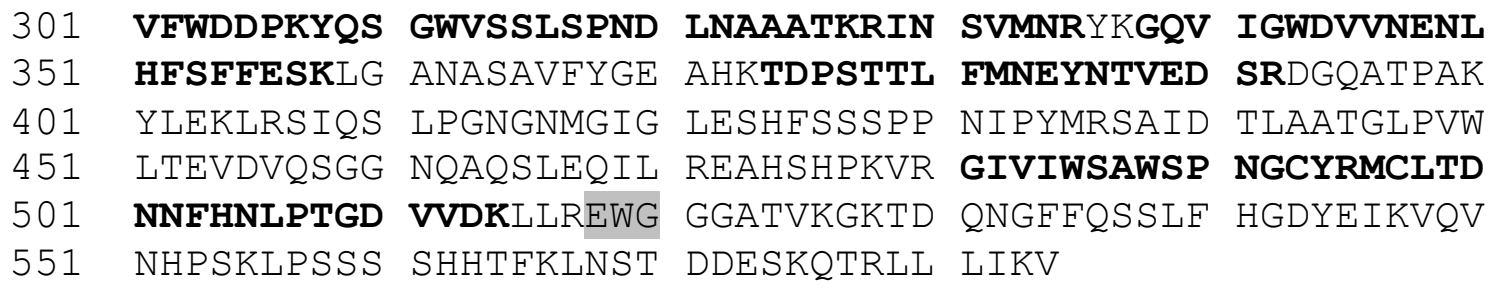

Table 1 Sugar composition of CTAB-insoluble pellets from papaya and tomato fruit $\mathrm{KOH}$-soluble extracts used as donor substrates for testing xylan endotransglycosylase activity. Values are means of two analyses. The standard deviation was $<2 \mathrm{~mol} \%$.

\begin{tabular}{lcccc}
\hline \multirow{2}{*}{ Sugar } & \multicolumn{4}{c}{ Sugar composition (mol\%) } \\
& \multicolumn{2}{c}{ Papaya } & \multicolumn{2}{c}{ Tomato } \\
& 1 M KOH & 4 M KOH & 1 M KOH & 4 M KOH \\
\hline Rhamnose & 2.0 & 1.8 & 4.6 & 4.5 \\
Fucose & 1.2 & 0.5 & 0.1 & 0.1 \\
Arabinose & 1.4 & 1.1 & 8.4 & 8.3 \\
Xylose & 56.9 & 54.5 & 53.5 & 35.0 \\
Mannose & 3.5 & 1.3 & 0.3 & 4.5 \\
Galactose & 2.9 & 3.6 & 5.5 & 7.1 \\
Glucose & 10.8 & 3.3 & 2.1 & 11.6 \\
Uronic acid & 21.3 & 34.0 & 25.7 & 28.7 \\
\hline
\end{tabular}

Table 2 Sugar linkages of galactoglucomannan-glucuronoxylan (GGM-GX) complexes derived from cell walls of ripe tomato. Both GGM-GX I and II contained about $5 \mathrm{~mol} \%$ of glucuronic acid (Prakash et al. 2012).

\begin{tabular}{lcc}
\hline Glycosyl linkage & GGM-GX I & GGM-GX II \\
(mol\%) & \\
\hline 4-Xyl & 23.0 & 10.0 \\
2-Xyl & 3.0 & n.d. \\
2,4-Xyl & 4.0 & n.d. \\
T-Xyl & $*$ & n.d. \\
\hline 4-Man & 11.0 & 37.0
\end{tabular}




\begin{tabular}{lcc} 
4,6-Man & 7.0 & 9.0 \\
\hline 4-Glc & 23.0 & 25.0 \\
4,6-Glc & 3.5 & 3.0 \\
T-Glc & 8.0 & n.d. \\
\hline 2-Gal & 4.0 & $*$ \\
4-Gal & n.d. & $*$ \\
T-Gal & 10.0 & 15.0 \\
\hline 5-Ara & $*$ & n.d. \\
T-Ara & $*$ & n.d.
\end{tabular}

*) present in trace amounts $(<0.5 \mathrm{~mol} \%)$; n.d. = not detected

Table 3 Activities of recombinant CpaEXY1 protein produced by transient over expression in Nicotiana benthamiana leaves using viral vector TTOSA1-XYL. Endoxylanase activity was assayed versus methyl-glucuronoxylan-RBB. Xylan endotransglycosylase activity was assayed using wheat arabinoxylan (WAX) and $\left[{ }^{3} \mathrm{H}\right]$ xylo-oligosaccharides.

\begin{tabular}{|c|c|c|c|}
\hline & $\begin{array}{l}\text { Protein in } \\
\text { extract }(\mu \mathrm{g})\end{array}$ & $\begin{array}{c}\text { Xylan endotransglycosylase } \\
\text { activity } \\
\text { (Bq inc kBq prov } \text { assay }^{-1} \text { ) }\end{array}$ & $\begin{array}{l}\text { Endoxylanase activity } \\
\qquad\left(A_{595} \text { assay }^{-1}\right)\end{array}$ \\
\hline Extract containing & 0.013 & $0.269 \pm 0.200$ & $0.005 \pm 0.007$ \\
\hline recombinant & 0.027 & $0.415 \pm 0.378$ & $0.007 \pm 0.004$ \\
\hline \multirow[t]{3}{*}{ CpaEXY1 protein } & 0.067 & $0.357 \pm 0.189$ & $0.010 \pm 0.010$ \\
\hline & 0.135 & $0.715 \pm 0.271$ & $0.031 \pm 0.010$ \\
\hline & 0.270 & $1.178 \pm 0.213$ & $0.069 \pm 0.003$ \\
\hline $\begin{array}{l}\text { Tobacco leaf } \\
\text { control }\end{array}$ & 0.270 & $0.150 \pm 0.060$ & $0.000 \pm 0.000$ \\
\hline
\end{tabular}




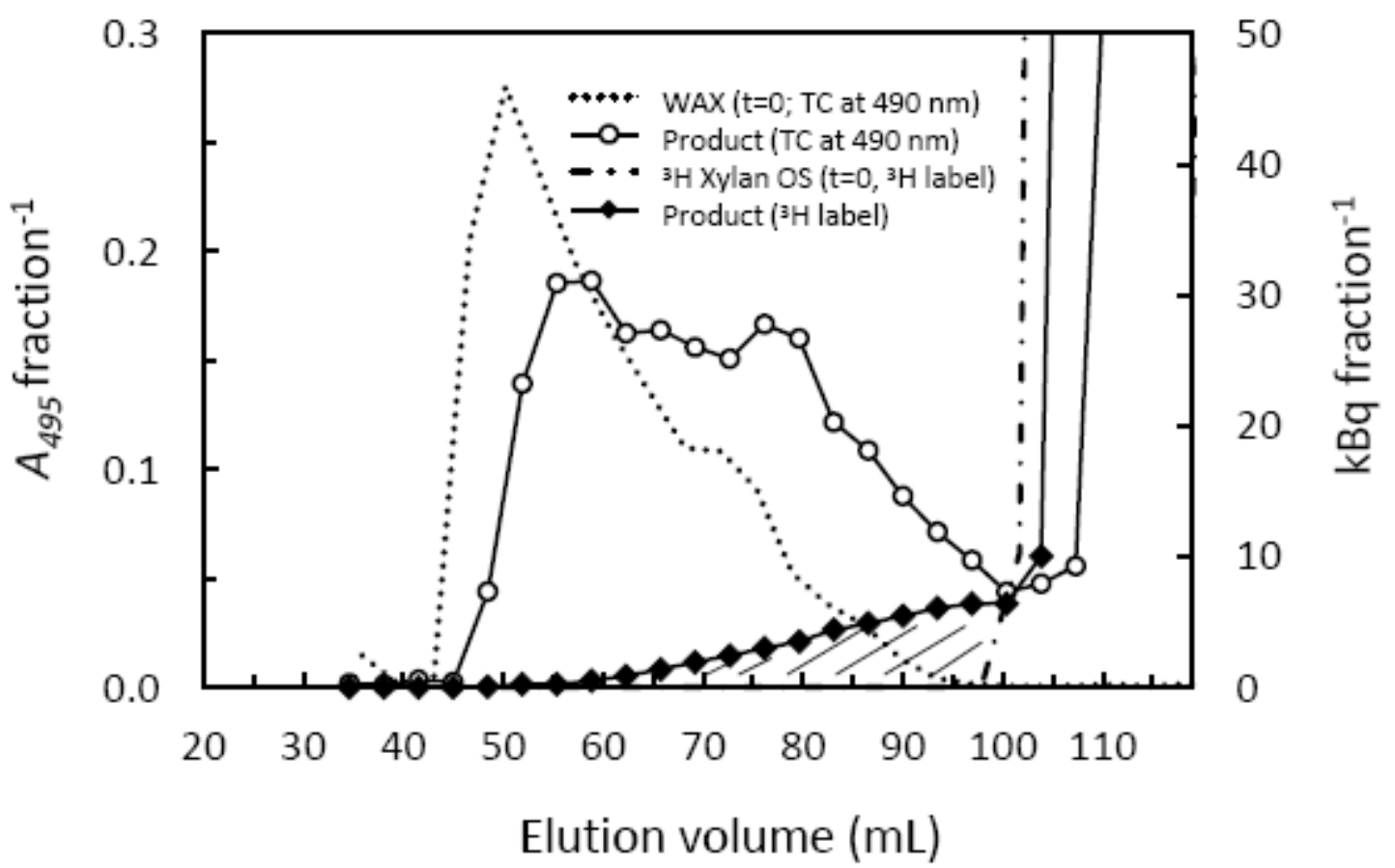

Figure 2

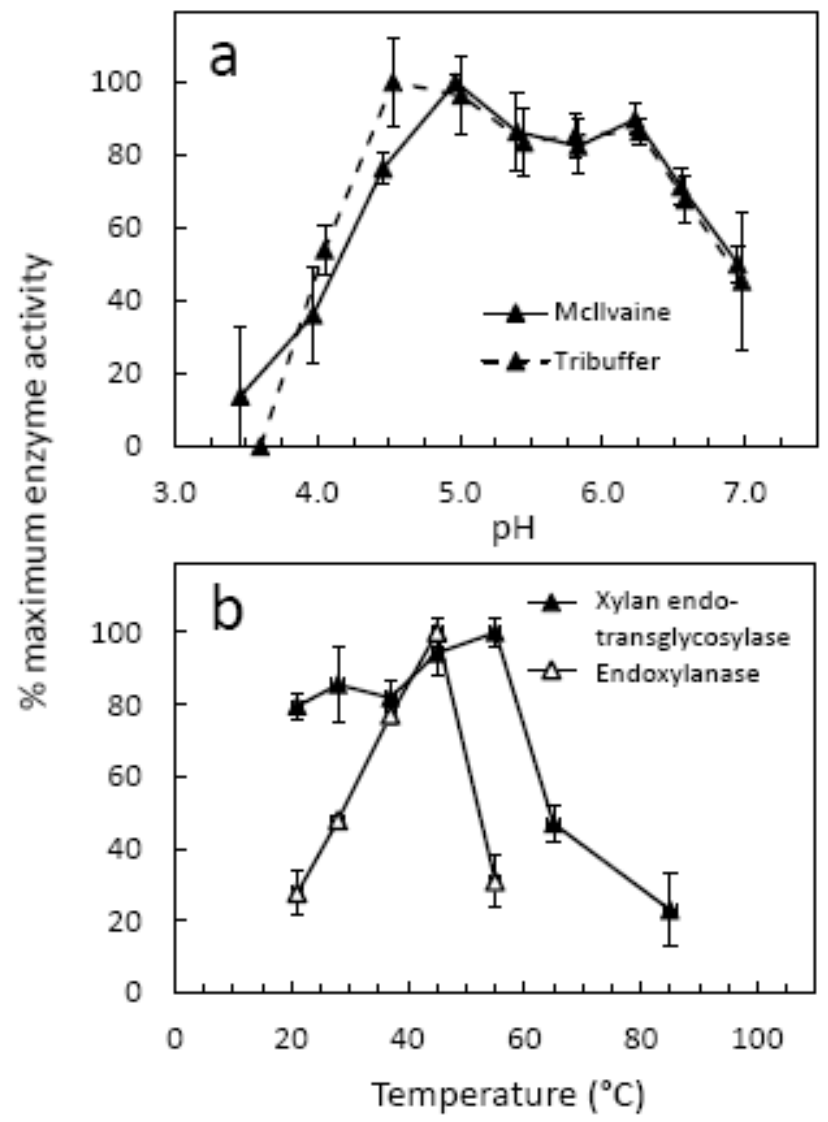


Figure 3

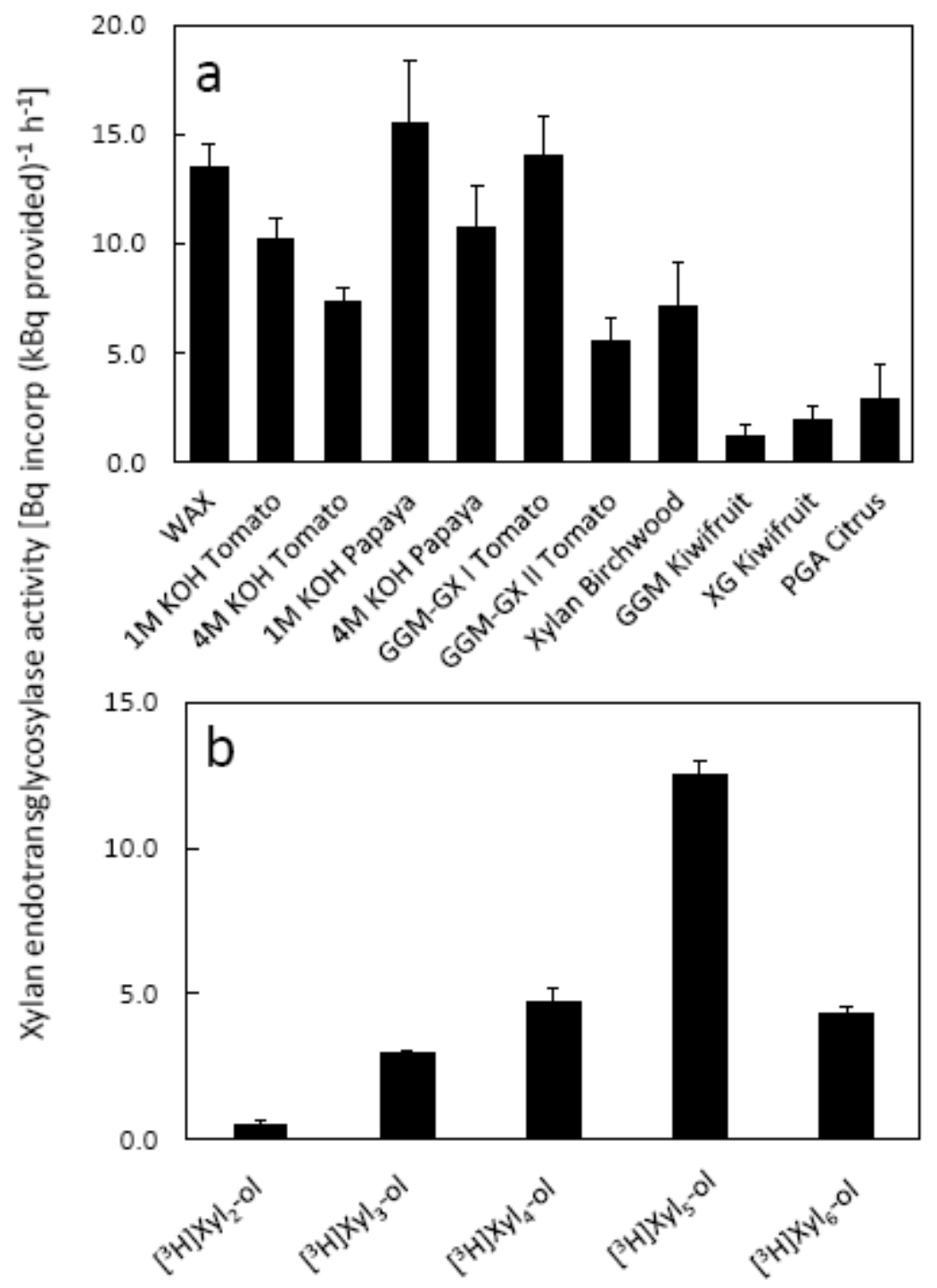




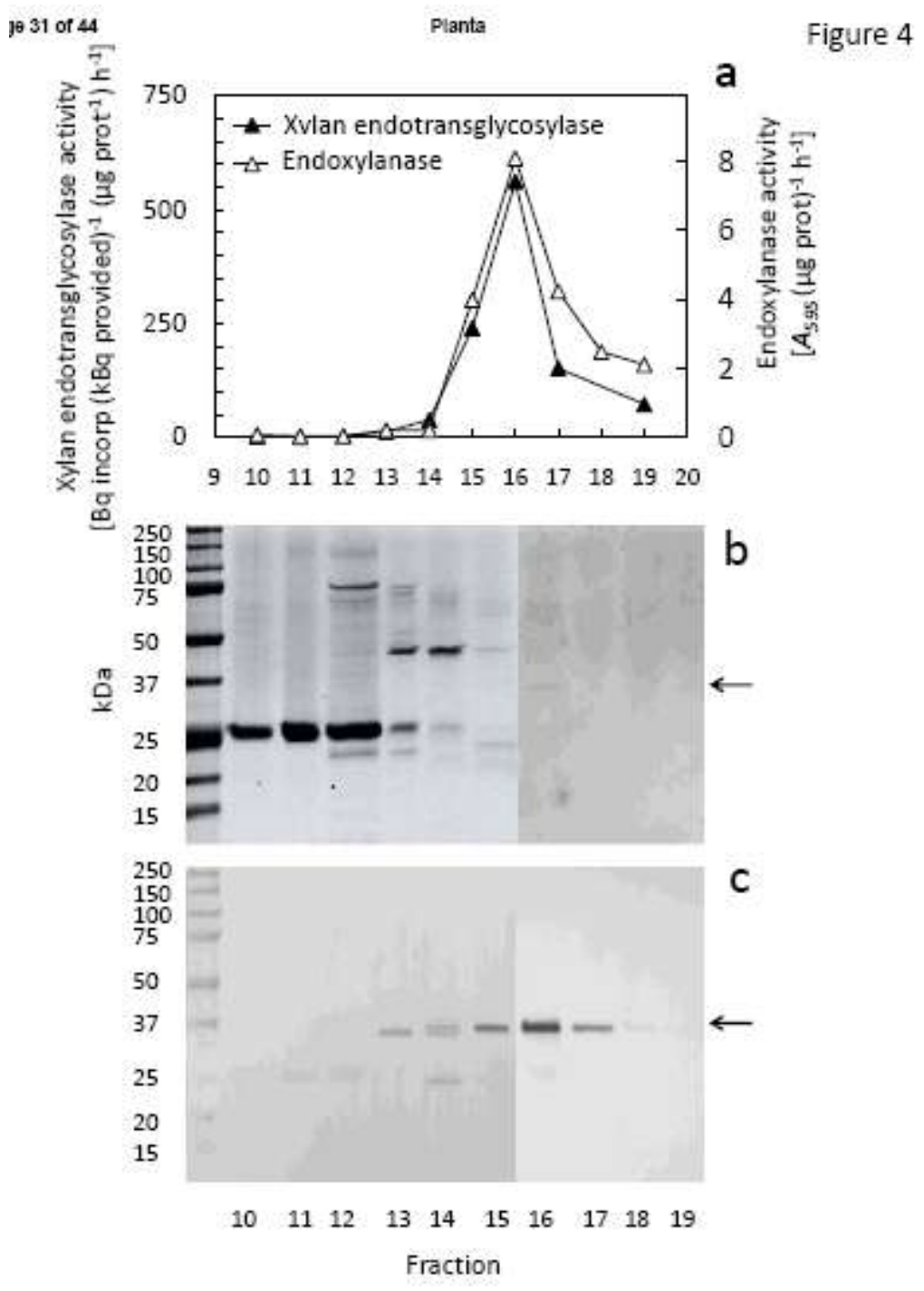

Figure 5

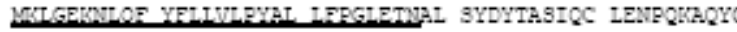
GGIITNPELN QGLWGWSTFG DAKIQHRVAG SNSEIVAHTR SQPHDBVSQ?

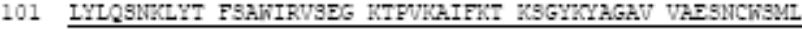

151 WGGLTVDASG PAELYFETIN TSVEIWIDSI BLQPFTQQEN RSHQDQSTKR

201 IRKKWVRIQA VDKLGIPLFN TTVSTSPIKI GFPRGCATRR NILMMRYYS

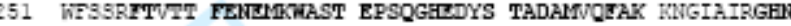

301 VIWDDPKYOS GWVSSLSPND LKAAATKRTA SVRRYIGOV IGWDVVIBNL

351 HTSETJSKLG ANASAVEYGE AHKTDPSTPL FMTYNMVD SRDGQATPA:

401 YIEKLRSIQ LPGIGNGIG LESHF39SPP NIPMRSAID TLAATGLF:

451 ITEVDWOSGG MAOSLEQTL REAHSHPIVR GIVTWSAMSP HECYRICLTD

501 MAFHRLPTG VVDKLLRENG GGATVKGKTD QMGFFQSSLF HGDYEIKVQV

551 NHPSKLPSS BHHTFLNST DDESKQTRLL LIKV 

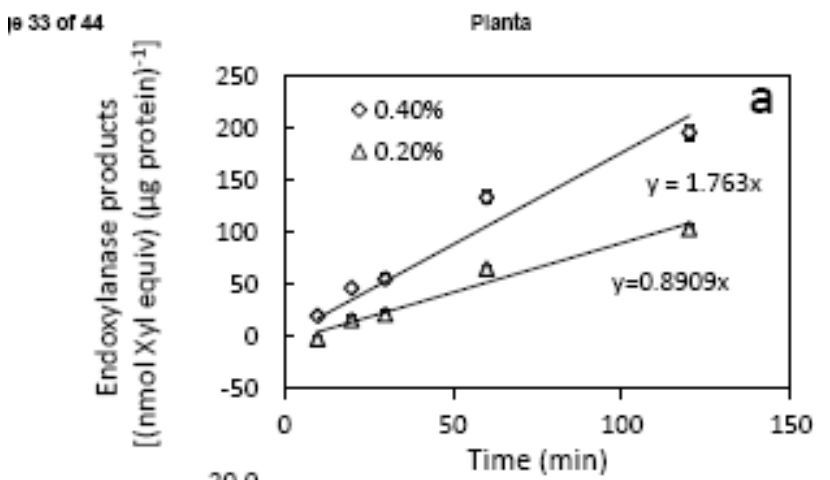

Figure 6
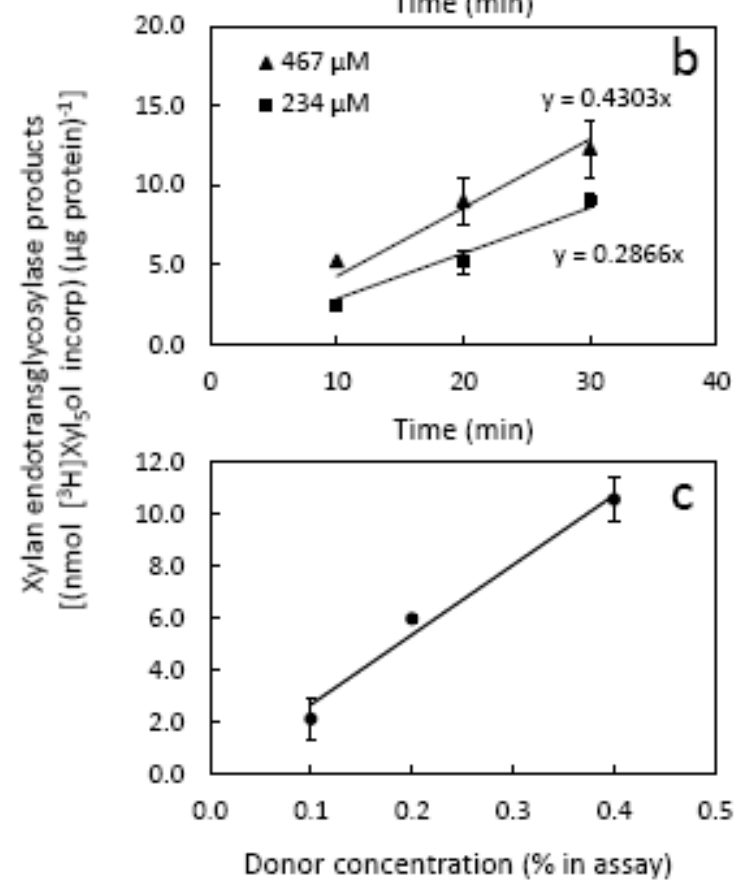


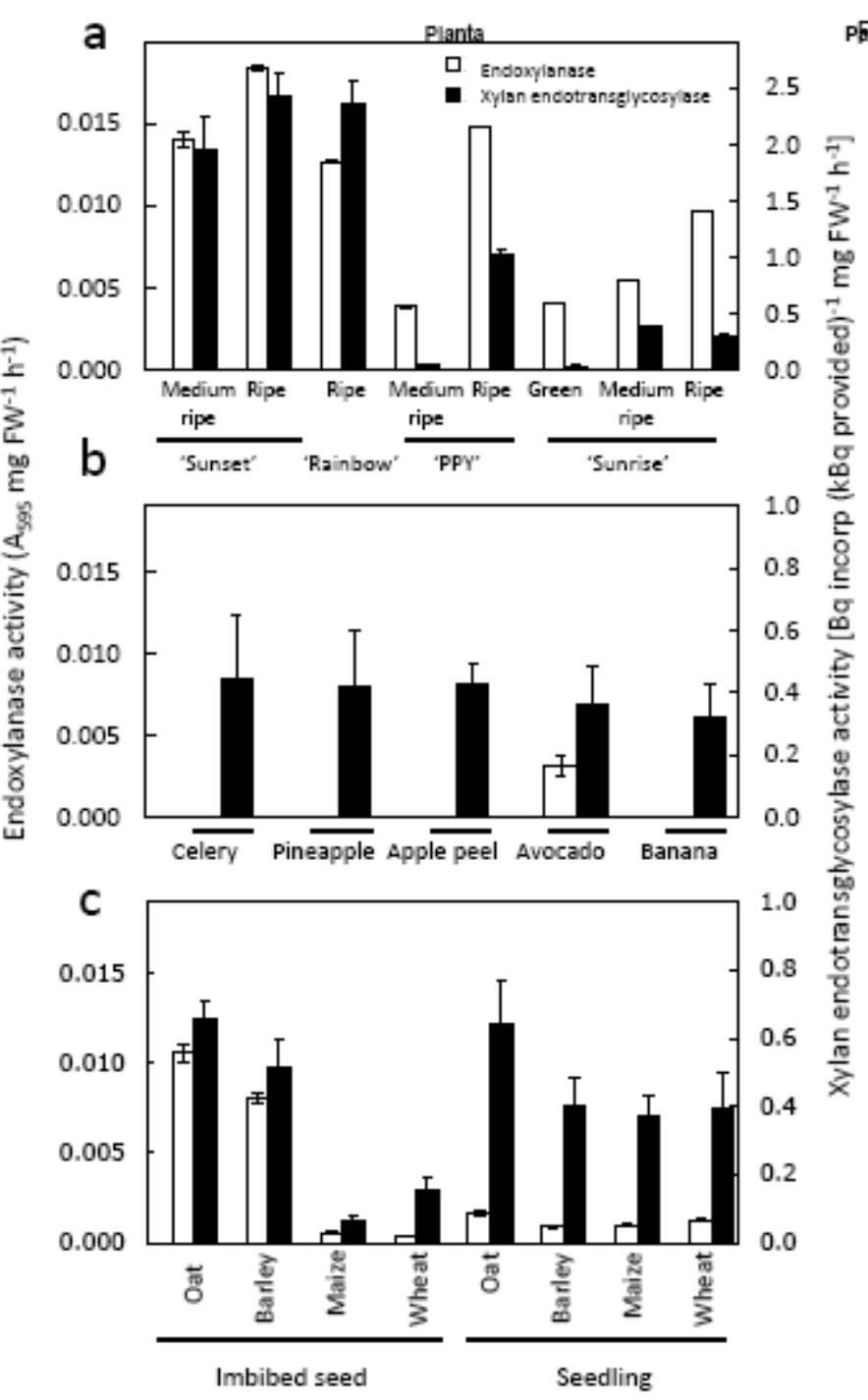

Pbjggra 44 